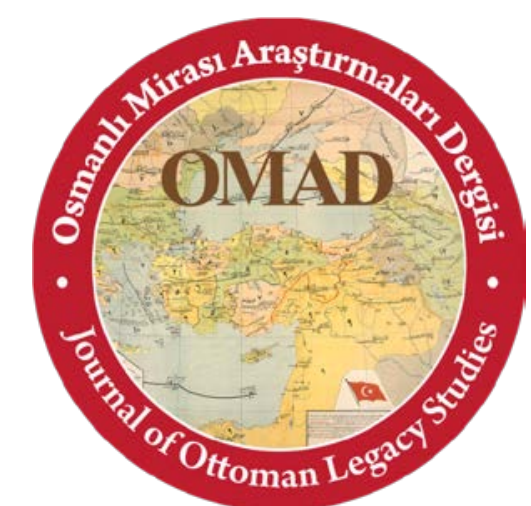

Osmanlı Mirası Araştırmalan Dergisi/Journal of Ottoman Legacy Studies

ISSN 2148-5704

www.osmanlimirasi.net

osmanlimirasi@gmail.com

Cilt 7, Sayı 19, Kasım 2020 / Volume 7, Issue 19, November 2020

\title{
SEYAHAT-NÂME TÜRÜNE FARKLI BİR ÖRNEK: FEVRÎ'NİN HAC SEYAHAT-NÂMESİ
}

A Different Example of the Type of Travel Book Travel: Fevri's the Pilgrimage Travel Book

\author{
Makale Türü/Article Types : Araştırma Makalesi/Research Article \\ Geliş Tarihi/Received Date : 16.05 .2020 \\ Kabul Tarihi/Accepted Date : 02.10 .2020 \\ Sayfa/Pages : 567-599 \\ DOI Numaras1/DOI Number : http://dx.doi.org/10.17822/omad.2020.171
}

\section{Yunus KAPLAN}

(Doç. Dr.), Osmaniye Korkut Ata Üniversitesi, Fen-Edebiyat Fakültesi, Türk Dili ve Edebiyatı Bölümü, Osmaniye / Türkiye, e-mail: yunuskaplan80@gmail.com, ORCID:

https://orcid.org/0000-0002-2421-253X

\section{$\underline{\text { Atıf/Citation }}$}

Kaplan, Yunus, "Seyahat-nâme Türüne Farklı Bir Örnek: Fevrî̀nin Hac Seyahat-nâmesi", Osmanlı Mirası Araştırmaları Dergisi, 7/19, 2020, s. 567-599. 



\title{
SEYAHAT-NÂME TÜRÜNE FARKLI BİR ÖRNEK: FEVRÎ’NIIN HAC SEYAHAT-NÂMESI
}

\author{
A Different Example of the Type of Travel Book Travel: Fevri's the Pilgrimage Travel Book
}

\author{
Yunus KAPLAN
}

Öz: Fevrî, Hırvat asıllı bir devşirme iken Müslüman olarak iyi bir eğitim görüp zamanla sahip olduğu ilmî meziyetler ve şairlikteki kudretiyle 16. yüzyılda haklı bir şöhreti yakalamış önemli bir divan şairidir. Onun bu şöhreti yakalamasında, yazmış olduğu ilmî ve edebî eserlerin büyük bir rolü olmuştur. Bu eserler arasında 1546 yılında hac ibadeti vesilesiyle çıkmış olduğu yolculuğu ve bu esnada yaşayıp gördüklerinin bir kısmını anlattığı manzum-mensur karışık şekilde kaleme aldığı Hac Seyahat-nâmesi de bulunmaktadır. Diğer eserlerin gölgesinde kalan ve şimdiye kadar üzerinde pek durulmayan bu Hac Seyahat-nâmesi, hem şairin farklı bir edebî veçhesini yansıtması hem de yazmış olduğu eserler arasında farklı bir türe sahip olması bakımından ayrı bir öneme haizdir. Bu eser, aynı zamanda klasik Türk edebiyatında örnekleri sınırlı sayıda olan hac seyahat-nâmesi türünde olması hasebiyle de önem arz etmektedir. Bu çalışmada şimdilik eldeki tek nüshasından hareketle Fevrî'nin Hac Seyahat-nâmesi'nin şekil ve muhteva özellikleri üzerinde birtakım değerlendirmelerde bulunularak eserin çeviri yazılı metnine yer verilmiştir.

Anahtar Kelimeler: Klasik Türk edebiyatı, 16. yüzyı1, Fevrî, hac, seyahat-nâme

Abstract: While Fevri was a devshirmeh of Croatian origin, he was one of the important Ottoman poets who received a great education as a Muslim and gained eligible reputation with his scholarly virtues and ability in being a poet in 16th century. The scholarly literary works that he wrote them became a great role for him to gain the reputation. Pilgrimage Travelbooks that he told the travel that he started out on the occassion of his duty of pilgrimage in 1546 and told a part of what he had and saw during the performance of the worship and he wrote in a mixed poetic-prose form is available among these works. His Pilgrimage Travelbooks which has been overshadowed of other works and has not been focused too much has a especial importance in terms that the poet reflected a different literary dialect and it has a different type among his works. Moreover, this work has an importance because it is in the type of pilgrimage itinerary that their samples are limited in the classic Turkish literature. In this research, a set of evaluations was made on the form and content features of Pilgrimage Travelbooks belonging to Fevri from the point of its available single copy and the work's text in translated and written form was included.

Keywords: Classical Turkish literature, 16th century, Fevrî, pilgrimage, travelbook

\section{Giriş}

İslam dininin inanç esasları ve buna bağlı temel kavramlar klasik Türk edebiyatının beslendiği ana damarlardan biri olmuştur. Hayat bulduğu Osmanlı toplumunun sahip olduğu maddi ve manevi hemen hemen her unsuru kendine malzeme olarak kullanan divan şairleri, bu toplumun benimsemiş olduğu İslam dinine ait unsurları da her firsatta değerlendirme yoluna gitmişlerdir. Bu unsurlar içinde İslam'ın beş farzından biri olan hac da yer almaktadır. Hem bedenen icra edilmesi hem de yapılabilmesi için maddi güç gerektiren bu ibadetle ilgili terimler, hac vazifesini ifa etmiş veya etmemiş olsun birçok şair tarafından çeşitli vesilelerle şiirlerde kullanılmıştır. Hatta zamanla edebiyatımızda konusu doğrudan veya dolaylı olarak hac ibadeti 
olan edebî türler dahi teşekkül etmiştir. Kâbe-nâme ${ }^{1}$, hac-nâme ${ }^{2}$, menzil-nâme ${ }^{3}$, menâsik-1 hac ${ }^{4}$ ve hac seyahat-nâmeleri bu türler arasında yer alır.

$\mathrm{Bu}$ çalışmada hac vazifesini yerine getirmek üzere yapılan yolculukta yaşanan tecrübelerin paylaşıldığı, hac güzergâhındaki yerleşim yerleri hakkında çeşitli bilgilerin verildiği ve yerine göre bu ibadetin rükünlerinin anlatıldığı Fevrî'nin manzum ve mensur karışık Hac Seyahat-nâmesi'nin tanıtımı yapılarak muhtevası hakkında birtakım değerlendirmelerde bulunulacaktır.

\section{Klasik Türk Edebiyatında Seyahat-nâmeler}

Arapça "gezmek, gezi" anlamındaki seyahat ve Farsça "nâme" kelimelerinden oluşan "gezi mektubu, gezi eseri" manasına gelen ${ }^{5}$ seyahat-nâmeler, edebî terim olarak çeşitli vesilelerle yapılan seyahatler dolayısıyla kaleme alınan eserler için kullanılan bir tabirdir.

Osmanlı toplumunda savaş, memuriyet, iş bulma, sürgün, eğitim, irşad ve hac gibi vesilelerle seyahat edilmesine rağmen 19. yüzyıla kadar oldukça az sayıda seyahat-nâme kaleme alınmıştır. Bunun en önemli sebebi, genellikle kişilerin bu yolculuklara farklı yerleri görmek ve anlatmak gibi bir maksatla çıkmamış olmalarıdır. Ayrıca Osmanlı toplumunda yolculuğun özellikle tahsilli kesim için hayatın bir parçası sayılması, seyahatlerin aynı medeniyet ve devlet sınırları içinde yapılmış olması da bu anlayışı desteklemiştir. Buna karşılık Pîrî Reis ve Seydi Ali Reis gibi denizciler, Mâcuncu-zâde Mustafa ve Temeşvarlı Osman Ağa gibi esirler ise Osmanlı coğrafyası dışında geçen hayatlarını yazmışlardır. ${ }^{6}$

Osmanlı ve İslam medeniyetinde yolculuk hâtıraları çoğunlukla hasbihal, sergüzeşt-nâme, gazavat-nâme, fetih-nâme, menzil-nâme, tarih, tezkire, esâret-nâme, sefâret-nâme ve takrir gibi diğer türler içinde yer bulabilmiştir. Dolayısıyla bu gibi eserler farklı özellikler taşımaktadır.

\subsection{Yolculuğun Esas Alındığı Seyahat-nâmeler:}

$\mathrm{Bu}$ eserlerin yazılmasındaki maksat, gezip görülen yerleri ve yaşanılan farklılıkları okuyucuyla paylaşmanın yanı sıra; okuyucuyu eğlendirmek, meraklandırmak, heyecanlandırmak ve üslubun izin verdiği ölçüde bilgilendirmektir. Evliya Çelebi’nin Seyahatnâme'sinin bazı kısımları, bazı yönleriyle Murâdî’nin Gazavât-ı Hayreddin Paşa'sı, Seydi Ali

\footnotetext{
${ }^{1}$ Türk edebiyatında Kâbe hakkında kaleme alınan eserler genel olarak Kâbe-nâme adıyla anılır. Bu ismi taşıdığı bilinen ilk eser Akşehirli Abdurrahman Gubârî'nin Kâbe-nâme adlı mesnevisidir. Safi'nin 1131 / 1719 yılında yazdığı Kâbe-nâme adlı mesneviyle Ali b. Osman el-Ûşî ve Ebü'l-Fazl Muhammed es-Sincarî’nin aynı adı taşıan eserleri de bu grupta yer almaktadır. Ayrıca menâsik-i hac ve menâzil-i hac türü eserlerde Kâbe ile ilgili manzum parçaların yer aldığı da görülmektedir. Gubârî’nin menâsik-i hac ve Kâbe'nin yapılışı ile ölçüleri hakkında bilgi veren mensur Mesâhat-nâme adlı kitaplarında Kâbe'ye dair bilgiler bulunmaktadır (Mustafa İsmet Uzun, "Kâbe", TDV İslam Ansiklopedisi, C. 24, TDV Yay., İstanbul 2001, s. 23).

${ }^{2}$ Bu türde dikkatleri çeken en önemli eser, Neccar-zâde Rızâ'nın Hac-nâme adlı risalesidir. 7 kasideden oluşan 265 beyitlik bir eserdir. Hepsi naat türünde şiirlerden oluşan bu eserin bu isimle adlandırılmasının sebebi muhtemelen şairin hac yolunda yahut mukaddes topraklarda iken yazmış olmasıdır (Ahmet Karataş, "Neccârzâde Şeyh Rızâ Efendi'nin Hacnâme’si”, Marmara Ü. İlâhiyat Fakültesi Dergisi, S. 43, 2012/2, s. 189).

${ }^{3}$ Menzil-nâmeler, çeşitli vesilelerle çıkılan seyahatlerde kervanların konakladıkları mekânlar veya yerleşim yerleri hakkında manzum veya mensur olarak kaleme alınan eserlerdir. Klasik Türk edebiyatında bu türdeki eserlerin büyük çoğunluğu hac seyahati esnasında konaklanılan menziller üzerine yazılmış olsa da İstanbul-Halep veya İstanbul-Mora gibi farklı menziller için yazılmış olanlara da tesadüf edilmektedir (Yunus Kaplan, "Seyyid Yahyâ Vâkıf Efendi ve Halep Menzil-nâmesi”, Littera Turca Journal of Turkish Language and Literature, 6/2, 2020 s. 214-17).

${ }^{4}$ Hacı olmak için Mekke'ye gidenlerin Kâbe ziyareti, Arafat'ta vakfeye durma, kurban kesme, ihram giyme, sa'y gibi yaptıkları ibadet rükünleri ile bunların yolunu, usulünü gösteren kitap (Devellioğlu 2011: 710) anlamına gelen menasik-i hac edebî terim olarak hacıların uyması gereken bu rükünler hakkında yazılmış olan eserlere denir. Gubârî (öl. 1566), Yusuf Sinaneddin bin Ya’kûb (öl. 1581), Nâlî Mehmed Efendi (öl. 1675) ve Kâmil’in (öl. 1894) yazmış olduğu eserler bu türün en meşhurlarıdır.

${ }^{5}$ Hüseyin Yazıc1, “Seyahat-nâme”, TDV İslam Ansiklopedisi, C. 37, TDV Yay., İstanbul 2009, s. 9.

${ }^{6}$ Menderes Coşkun, "Seyahat-nâme”, TDV İslam Ansiklopedisi, C. 37, TDV Yay., İstanbul 2009, s. 13.

${ }^{7}$ Menderes Coşkun, agm., s. 13.
} 
Reis'in Mir'âtü'l-Memâlik'i, Temeşvarlı Osman Ağa'nın hatıraları ve Bayburtlu Zihnî'nin Hikâye-i Garîbe'si bu türde kaleme alınmış eserlerdir. ${ }^{8}$

\subsection{Esaret-nâmeler}

Osmanlıların farklı medeniyetler ile temaslarını sefaret-nâmelerden daha önce ifade eden eserlerdir. Bunların bazılarında müellif, hatıralarını yazma gerekçesini herkesin gidemeyeceği bir ülke ve medeniyette bulunma olarak göstermiştir. Mektup şeklinde kaleme alınmış olanlar dâhil çok az esir, yabancı bir ülkede başından geçenleri yazıya dökmüştür. Bazıları seyahatnâme niteliği taşıyan ve münşeat mecmualarında rastlanan bu mektupların yazılış sebepleri, ya müellifin içinde bulunduğu durumu dostlarına bildirmek istemesi ya da korsanlar tarafindan kendisinden istenen fidyeyi memleketteki dostlarının yardımıyla temin ederek esaretten kurtulma arzusudur. Cem Sultan'ın ölümünden yirmi yıl sonra günlük tarzında yazılan Vâkı'ât-ı Sultân Cem'i, Macuncuzade Mustafa'nın Sergüzeşt-i Esîr-i Malta'sı, Yusuf Efendi'nin Makâle-i Zindancı Mahmud Kapudan Berâ-yı Feth ü Zafer-i Keştî-i Maltiz-i La'în Duzâh-mekîn'i ve Temeşvarlı Osman Ağa'nın eserleri bu tarzdadır. ${ }^{9}$

\subsection{Sergüzeşt-nâme ve Hasbihâl Türünde Yazlan Manzum Seyahat-nâmeler}

$\mathrm{Bu}$ türdeki eserlerin önemli kısmında şairin amacı, hayatta ve özellikle gurbette çektiği sıkıntıları anlatmaktır. Sergüzeşt-nâme ve hasbihâl türünde yazılmış olan başlıca eserler şunlardır: Şeyhî'nin Har-nâme'si, Cemâlî’nin Der-Beyân-ı Meşakkat-i Sefer ü Zaruret ü Mülâzemet'i, İsmail Belîğ'in Sergüzeşt-nâme-i Fakîr-i be-Azîmet-i Tokat'1, Mîr Rizâ-y1 İstolçevi'nin Sergüzeşt-i Fakîr ü Hakîr-i Pür-Taksîr'i, Ahmed bin İbrahim Tokadî'nin Acâ'ibnâme-i Hindustân'1, İzzet Molla'nın Mihnet Keşan'1 ve Bayburtlu Zihnî’nin Sergüzeştnâme'sidir. ${ }^{10}$

\subsection{Sefâret-nâmeler}

Siyaset ve tarih ilmine katkıda bulunmak için yazılmış resmî seyahat-nâmelerdir. Türk edebiyatındaki ilk sefâret-nâme, 1665 yılında büyükelçi sıfatıyla Viyana'ya gönderilen Kara Mehmed Paşa tarafından kaleme alınmıştır. Son sefâret-nâme ise Abdürrezzâk Bâhir Efendi’nin 1845'te Risâle-i Sagîre adıyla yazdığı Paris-Londra sefâret-nâmesidir. Sefâret-nâmelerin bir kısmı elçilerin maiyetinde bulunan bir edip veya şair tarafından bazen manzum olarak kaleme alınmıştır. Bu türün en meşhuru 1720 yılında Paris'e gönderilen Yirmisekiz Çelebi Mehmed'in Fransa Sefâret-nâmesi'dir. ${ }^{11}$ Sefaret-nâme yazma geleneği 18 . yüzyıldan itibaren yaygınlık kazanmış; özellikle Osmanlı Devleti'nin daha çok temasta bulunduğu Fransa, Rusya, Prusya (Almanya), Avusturya, İtalya, İspanya ve İran gibi devletlere gönderilen elçilerin yazdıkları bu ülkelerle ilgili ayrıntılı bilgiler içerir.

\subsection{Hac Seyahat-nâmeleri}

Arapça bir kelime olan hacc "Tartışarak yenmek, ikna etmek, bir şeyden feragat etmek, bir yerden gelmek, bir kimse ya da mahalle çok gidip gelmek" "2; "İslam'ın beş şartından biri olan ve muayyen bir zamanda Mekke'deki Kâbe-i Şerîfe'yi ziyaret etmek üzere yola çıkma farizası, hacca gitme, hac görevini yapma" ${ }^{13}$ anlamına gelmektedir.

İslam'da haccın maddi gücü yeten ve belli şartlara haiz tüm Müslümanlara farz kılınması ile birlikte bu ibadetin yerine getirilmesi için Müslüman devletler tarafindan çeşitli tertibatlar

\footnotetext{
${ }^{8}$ Menderes Coşkun, Bosnalı Muhlis'in Manzum Seyahatnamesi Delîlü'l-Menâhil ve Mürşidü'l-Merâhil, Fakülte Kitabevi, Isparta 2007, s. 11.

${ }^{9}$ Menderes Coşkun, age., s. 13-16.

${ }^{10}$ Menderes Coşkun, age., s. 16-18.

${ }^{11}$ Menderes Coşkun, age., s. 27.

${ }^{12}$ Serdar Mutçall, Arapça-Türkçe Sözlük, Dağarcık Yay., İstanbul 1995, s. 148.

${ }^{13}$ Ferit Devellioğlu, Ansiklopedik Osmanlıca-Türkçe Lûgat, Aydın Kitabevi, Ankara 2011, s. 350; Mehmet Kanar, Osmanlı Türkçesi Sözlüğ̈̈, Say Yay., İstanbul 2009, s. 1137.
} 
yapılmıştır. Hacca giden kimselerin kullanmaları için belirli yol güzergâhları ve bu yollar üzerinde hacıların konaklayıp faydalanabilecekleri menziller oluşturulmuştur. ${ }^{14} \mathrm{Bu}$ yol güzergâhları ve menziller bölgeye hâkim olan siyasî otoriteler tarafından zaman ve iklim şartlarına göre değişiklik yapılarak kullanılmışlardır. ${ }^{15}$

Her yıl muayyen dönemlerde hac kervanlarının düzenlenmesi ve bu süreçte bir devamlılık sağlanması, Hicaz'ın ilhakı ve Osmanlı sultanlarının "Hâdimü'l-Harameyn" unvanını almasından sonra, Osmanlı yönetimi açısından büyük bir önem kazanmıştır. Bu kervanlarla hacca gidenlerden bazıları, o dönemdeki ulaşım vasıtalarının taşıma kapasitesi ve iletim imkânlarının yetersizliği sebebi ile ortalama 8-9 ay süren yolculuklarını ve seyahatlerini tasvir eden eserler kaleme almışlardır. Bu eserlerde genellikle hacıların yol güzergâhları, konaklama ve oturak menzilleri tanıtılarak, hac yolculuğunun nasıl yapıldığına dair bilgilere yer verilir. Ayrıca menzillerde bulunan ziyaretgâh ve türbelerin isimleri verilerek menzilin dikkat çeken önemli özellikleri ile bölge hakkında anlatılan rivayetlerden de bahsedilir. Bunun yanında, bu eserleri kaleme alan hacılar bizzat başlarından geçen ve şahit oldukları olaylardan ziyade, geçtikleri ve gördükleri yerlerde hacıların ihtiyaç duyabileceği su ve diğer emtianın bulunup bulunmadığı hususunda da bilgiler sunarlar. ${ }^{16}$

Bu eserler, İstanbul'dan Mekke'ye kadar uzanan çok geniş bir coğrafya ile ilgili dolaylı fakat önemli bilgiler vermekle birlikte aynı zamanda yazarlarının düşünce yapıları, inançları, eğitimleri ve dilleri hakkında dolaylı bilgiler de içermektedir. ${ }^{17}$

Klasik Türk edebiyatında konu itibarıyla doğrudan veya dolaylı olarak hacdan bahseden menzil-nâmeler ve menâsiklar hac seyahat-nâmeleriyle iç içe geçmiş bir tür olarak karşımıza çıkmaktadır. Menzil-nâmeler hac kervanlarının konakladıkları menziller, menâsik-nâmeler ise hac ibadetinin rükünleri hakkında bilgi veren eserlerdir. Ancak bu türlerde kaleme alınan eserlerin çoğunda, bu türlerin sahip olduğu temel özelliklerle birlikte seyahat-nâme özelliklerine de tesadüf edilmektedir. Hatta bazı eserler bu üç türe dâhil edilebilecek şekilde telif edilmiştir.

Klasik Türk edebiyatında gerek tamamen seyahatname gerekse hem menzil-nâme hem de menâsik özelliği gösteren hac seyahat-nâmesi türünde kaleme alınan belli başlı eserler şunlardır:

1.5.1. Ahmed Fakîh, Kitâbü Evsâf-ı Mesâcid-i Şerîfe: Osmanlı hac seyahat-nâmelerinin en eskisi kabul edilen eserde seyahat sırasında ziyaret edilen Kudüs, Medine ve Mekke olmak üzere üç kutsal şehir hakkındaki izlenim ve bilgilere yer verilmiştir. ${ }^{18}$

\subsubsection{Fevrî, Hac Seyahat-nâmesi: Eser hakkında aşağıda ayrıntılı bilgi verilecektir.}

1.5.3. Abdurrahman Hibrî, Menâsik-ı Mesâlik: Abdurrahman Hibrî (1604-1659)’nin kaleme aldığı eserde, 1632 yılında yaptığı hac seyahatinde gidiş ve dönüşteki yollar ve uğranılan yerler hakkında geniş bilgi verilmiş ve hac menâsiki bütün ayrıntılarıyla anlatılmıştır. Önce Edirne'den Şam'a kadar olan menziller hakkında bilgi verilmiş, ardından Şam'dan Antakya'ya kadar olan dönüş yolu anlatılmıştır. Daha sonra Şam'dan Mekke'ye kadar olan menziller siralanarak seyahat esnasında İstanbul, Anadolu ve Hicaz'da meydana gelen olaylar; haccın nasıl yapılacağı, hac sırasında okunacak dualar ve sureler ile Peygamberin kabrinin ziyareti anlatılmıştır. ${ }^{19}$

\footnotetext{
${ }^{14}$ Suat Donuk, "Servet Mahlaslı Bir Şaire Mâl Edilen Manzum Bir Hac Seyahatnamesi”, Selçuk Ü. Türkiyat Araştırmaları Dergisi, S. 41, 2017, s. 53.

15 İzzet Sak ve Cemal Çetin, "XVII. ve XVIII. Yüzyıllarda Osmanlı Hac Menzilleri”, Selçuk Ü. İlahiyat Fakültesi Dergisi, S. 19, 2005, s. 199-200.

${ }^{16}$ İzzet Sak ve Cemal Çetin, agm., s. 210.

${ }^{17}$ Menderes Coşkun, Manzum ve Mensur Osmanlı Hac Seyahatnameleri ve Nâbî’nin Tuhfetü'l-Harameyn'i, Kültür Bakanlığı Yay., Ankara 2002, s. 3.

${ }^{18}$ Menderes Coşkun, age., s. 42.

${ }^{19}$ Sevim İlgürel, “Abdurrahman Hibrî'nin Menâsık-i Mesâlik'i”, İstanbul Ü. Edebiyat Fakültesi Tarih Enstitüsü Dergisi, (6), 1975, s. 111-12.
} 
1.5.4. Bosnalı Hacı Yusuf, Hac Seyahat-nâmesi: Hac farizasını yerine getirmek için 20 Haziran 1615 tarihinde memleketi Zupon'dan yola çıkan Hacı Yusuf, karayoluyla önce İstanbul'a buradan da denizyoluyla Kahire'ye gelmiş; Süveyş'te tekrar gemi vasitasiyla Kızıldeniz üzerinden Cidde'ye ve en son Mekke'ye ulaşmıştır. Hac görevini ifa ettikten sonra karayolu ile Kahire'ye, sonra gemiyle İskenderiye'den Selânik'e gelerek tekrar karayolu ile Üsküp ve Saraybosna'ya, buradan ise Duvno'ya ulaşarak yolculuğunu tamamlamıştır. Yazar bu seyahati esnasında konakladıkları yerler, uğradıkları mekânlar ve ziyaret ettikleri evliyalar ve bunların türbeleri hakkında bilgiler vermiştir. Hacı Yusuf, gördüğü yerler ve orada bulunan tarihi eserleri gerçekçi bir anlatımla kaydederek ayrıntılı tasvirler yapmıştır. ${ }^{20}$

1.5.5. Hacı Ali Efendi, Tuhfetü'l-Huccâc: Hac seyahat-nâmesi olarak kaleme alınan eserde Hacı Ali Efendi, 1647-48 yılında gittiği hac yolculuğunu anlatmıştır. Eserde Üsküdar'dan kutsal topraklara uzanan hac yolu menzilleri, güzergâhtaki şehirler ile buralardaki evliyanın metfun bulunduğu ziyaretgâhlar konu edilmektedir. Üsküdar-Mina arasında geçilen belli başlı menzil ve şehirler hakkında sahip oldukları önem ve özelliklerine göre uzun ya da kısa bilgiler verilir. Ayrıca haccın farz, vacip, sünnet ve müstehapları belirtilmiş; ihrama girme kurallarına değinilmiş; hacca ve umreye nasıl niyet edileceği anlatılmıştır. ${ }^{21}$

1.5.6. Nâbî, Tuhfetü'l-Harameyn: Nâbî'nin 1678-79 yıllarında Urfa, Şam, Kudüs ve Kahire üzerinden gerçekleştirdiği hac yolculuğunu manzum-mensur anlatan bir eserdir. Hac seyahat-nâmeleri içinde en meşhuru ve en edebîsi olan bu eserde Nâbî, resmî hac kervanına katılarak yolculuğunu daha güvenli yapmak yerine Kahire üzerinden daha tehlikeli ve uzun bir yolculuğu tercih etmiştir. Kartal, İzmit, Hersek ve İznik yoluyla Eskişehir'e ulaşan Nâbî; Akşehir, Ilgın, Lâdik, Konya, Ereğli, Adana, Payas ve Antakya üzerinden Halep'e varır ve bir müddet burada kalır. Buradan Hama, Humus üzerinden Şam'a gider. Kudüs ve Gazze üzerinden Kahire'ye ulaşan şair, bir müddet burada kaldıktan sonra Mısır hac kervanına katılarak Adiliyye, Birke, Tih Sahrası, Sina Dağı, Mısır Akabesi, Bedr-i Huneyn ve Râbiğ üzerinden Mekke'ye ulaşır. Nâbî, hac güzergâhındaki yerleşim yerlerinden ziyaret edilecek bir türbe, tarihî bir cami veya binası olanların tavsifini yapmış; eğer bunlar yoksa oranın tavsifini pek önemsememiştir. ${ }^{22}$

1.5.7. Servet, Manzum Hac Seyahat-nâmesi: 17. yüzyılda veya öncesinde yaşadığı tahmin edilen Servet mahlaslı bir şair tarafından mesnevi nazım şekliyle kaleme alınmıştır. Klasik mesnevi formunda olmayan eser, 135 beyit ile 9 dörtlük olmak üzere toplam 144 nazım biriminden müteşekkildir. Mesnevi kısmını oluşturan bölümler, üç farklı aruz kalıbıyla yazılmıştır. Manzum hac seyahat-nâmesi özelliği taşıyan eserde şair, Pendik’ten başlayarak Konya, Halep ve Şam güzergâhından Mekke'ye kadar olan konaklar ve buraların sahip olduğu bazı özellikler hakkında sade bir dil ve canlı bir üslupla bilgi vermiştir. ${ }^{23}$

1.5.8. Kadrî, Menâzilü't-Tarîk ilâ Beyti'llâhi'l-Atîk: 17. yüzyılda yaşamış olan Kadrî mahlaslı biri tarafından yazılan eser, rehber nitelikli mensur bir hac seyahat-nâmesi olup müstakbel hacılara faydalı bilgiler vermek amacıyla yazılmıştır. Sekiz bölümden oluşan eserde hacıların yolculuk esnasında nelere dikkat etmeleri gerektiği hakkında bilgi verilip tavsiyelerde bulunulmuş, Üsküdar-Şam-Medine ve Mekke güzergâhındaki menzillerin tasviri yapılmıştır. Konaklar arası mesafe, konakların durumu ve buralardaki kamuya ait binalar hakkında bilgiler veren Kadrî, bu anlatımlarda hem kendi izlenimlerine hem de yazılı ve sözlü kaynaklara başvurmuştur. $^{24}$

20 A. Rıza Özuygun-Şefika Yapıcı, "Bosnalı Hacı Yusuf Livnjak’ın Hac Seyahatnamesi”, Sosyal Bilimler Araştırmaları Dergisi, S. I, 2014. s. 36-74

${ }^{21}$ Sadettin Baştürk, "Bir Hac Yolcusunun Gözünden İstanbul'dan Hicaz'a Osmanlı Şehirleri”, Journal of Human Sciences, (10)1, 2013, s. 148-161.

${ }^{22}$ Menderes Coşkun, age., s. 86-88.

${ }^{23}$ Suat Donuk, agm., s. 17-21.

${ }^{24}$ Menderes Coşkun, age., s. 24-26. 
1.5.9. Nâtık, Tuhfetü'l-Harameyn: Edirneli Nâtık tarafından 1707 yılında kaleme alınmıştır. Mesnevi nazım şekli ve aruzun fe'ilâtün mefâ'ilün fe'ilün kalıbıyla yazılan eser, 2789 beyittir. Şair, 1706 yılında çıktığı hac yolculuğunu ve bu yolculuk esnasında ziyaret ettiği yerleri anlatmıştır. Eserinin ağırlık noktasını hac farizasının yerine getirilmesinin gerekliliği, Mekke ve Medine ile buralardaki kutsal mekânların tanıtımı, ziyaretçilerin buralarda nasıl davranıp neler yapmaları gerektiği oluşturur. Seyahatinde deniz yolunu kullanan Nâtık; KahireMekke arasındaki menzillerin havası, suyu ve toprağı gibi iklimsel özellikleri hakkında bilgi vermiş; kimi zaman da kendi başından geçen olayları veya gezdiği yerlerle ilgili kimi önemli olayları anlatmıştır. ${ }^{25}$

1.5.10. Bosnalı Muhlis, Delîlü'l-Menâhil ve Mürşidü'l-Merâhil: Manzum bir hac seyahat-nâmesi olan eser, 18. yüzyıl şairlerinden Bosnalı Muhlis tarafindan 1748-49 yılında çıkmış olduğu hac seferi için kaleme alınmıştır. 891 beyit tutarındaki eser, mefâ'îlün mefâ'îlün $f e$ 'ûlün vezniyle yazılmıştır. Eserin bu türdeki diğer eserlerden en büyük fark1, müellifinin İstanbul'dan Misır'a kadarki yolculuğunda deniz yolunu kullanması ve bu güzergâhtaki menziller hakkında daha ayrıntılı bilgiler vermesidir. Menâzil tipi hac seyahat-nâmelerinden biri olan eserde Muhlis; Kahire ile Mekke arasındaki 30 menzilin tavsifini yapmıştır. ${ }^{26}$

1.5.11. Cûdî, Merâhilü Mekke Mine'ş-Şâm: Cûdî mahlaslı bir şair tarafından 1756 yılında, kaside nazım şekli ve aruz vezninin mefâ'îlün mefâ'îlün mefâ'îlün mefâ'îlün kalıbıyla yazılmıştır. 278 beyit tutarındaki eserde, Şam'dan Mekke'ye kadar olan hacıların uğradığı konaklar sade bir dille anlatılmıştır. ${ }^{27}$

1.5.12. Mehmed Edîb Bin Mehmed Derviş, Behcetü’l-Menâzil: Mehmed Edîb bin Mehmed Derviş tarafindan mensur bir şekilde yazılan bu eserde, hacca gidecek kişilerin nelere dikkat etmeleri gerektiği anlatılmaktadır. 7 Eylül 1776 tarihinde Maltepe'den yola çıkan yazar, Kartal'dan itibaren İstanbul'dan Mekke'ye kadarki güzergâhta bulunan yerleşim yerlerini tek tek kaydederek bunlar hakkında ayrıntılı bilgiler vermiştir. Menzillerin bulunduğu yerleşim yerlerinde bulunan yapıların sayılarını veren yazar; iki menzil arasındaki mesafeleri ve aralarında bulunan yerleşim merkezlerinin adları ve özelliklerinden de söz etmiştir. Geçtiği yerlerin coğrafi özelliklerini, dağlarını, yaylalarını, ovalarını, ırmaklarını, körfezlerini ismen belirtirken bazılarında ise betimlemeler yapmıştır. Diğer yandan menzillerde bulunan su miktarı, bu yörelerde hangi meyvelerin yetiştirildiğini, bazı yörelerde yapılan el sanatlarından, evcil veya yabani hayvanlardan da bahsetmiştir. ${ }^{28}$

1.5.13. Seyyid İbrahim Hanîf, Hâsıl-ı Hacc-ı Şerîf li-Menâzili’l-Harameyn: İbrahim Hanîf'in 1787-88 yılında yapmış olduğu hac yolculuğunu anlatan eser, manzum-mensur karışıktır. Konunun işlenişi bakımından rehber nitelikli diğer hac seyahat-nâmelerinden farklılıklar gösterir. Eser, hacıları neşelendirmek için hazırlanmış hikâye ve şiirlerle doludur. Menziller ve yolculukla ilgili bilgiler, bu birbirinden bağımsız hikâye ve şiirleri çerçevelemektedir. ${ }^{29}$ Üsküdar'dan yola çıkan Hanîf; Gebze, Eskişehir, Konya, Adana ve Şam hattı üzerinden son durak Medine ve Mekke'ye varmıştır. Anadolu'daki şehir ve kasabalar hakkında ayrıntılı bilgiler veren şair, Şam'dan sonraki yerlerin daha çok han ve kale isimlerini zikretmekle yetinmiştir. ${ }^{30}$

\footnotetext{
25 İ. Hakk1 Aksoyak, "Nâbî'nin Tuhfetü'l-Haremeyn'inin Edirneli Nâtık'1n Tuhfetü'l-Haremeyn'ine Etkisi: Hikâyeler, Gelenekler, İnanışlar...", Milli Folklor, Yıl 24, S. 95, 2012, s. 10-14.

${ }^{26}$ Menderes Coşkun, Bosnalı..., s. 30-31.

27 Fatih Koyuncu, Cûdî’nin Manzum Hac Seyahat-nâmesi, Littera Turca Journal of Turkish Language and Literature, Volume 3, Issue 1, 2017, s. 177-219.

${ }^{28}$ Serbülent Karadağ, Mehmed Edib Bin Mehmed Derviş'in “Behcet'ül Menazil”" Adlı Eserinin Transkrip ve Tahlili, YLT, Hatay 2011, s. 48-49.

${ }^{29}$ Menderes Coşkun, Manzum..., s. 27.

${ }^{30}$ Nurhan Ramazanoğlu Özcan, Seyyid İbrahim Hanîfin (ö. 1802) Hayatı, Eserleri ve Hâsıl-ı Hacc-ı Şerîf LiMenâzi'l-Harameyn Adlı Eserin Incelenmesi, YLT, Ankara 2011.
} 


\section{Fevrî’nin Hac Seyahat-nâmesi}

\subsection{Fevrî'nin Hayatı}

Arnavutluk'a bağlı Draç'ta doğdu. Hırvat asıllı Hristiyan bir aileye mensuptu. Küçük yaşta İstanbul'a getirildi. Ferhad Paşa'nın kethüdası Pulad'ın ve sonra kardeşi Cafer Kethüda'nın himayesine girdi. Rumeli Beylerbeyi Lutfi Paşa'ya takdim edilen Ahmed Fevrî, Paşa'ya sunduğu "sûsen" redifli kaside ile hürriyetine kavuştu. Latîfî ve Hasan Çelebi'ye göre Lâmiî Çelebi'nin dedesi Nakkaş Ali Çelebi'nin, Gelibolulu Mustafa Âlî’ye göreyse İskender Çelebi'nin himayesinde yetişmiştir.

Dönemin tanınmış bilginlerinden Dursun Efendi, Taşköprizâde Ahmed Efendi ve Arabzâde Abdülbâkî Efendi'den eğitim gören Fevrî; Bostan Çelebi'nin Bursa kadılığı sırasında ondan mülazım oldu. 952 / 1544 yılında y1lından hacca gitti. 1547'de Edirne Anbar Kadı Medresesine müderris tayin edildi. 1548 yllında Edirne'ye gelen Şehzade Selim'e intisap etti. Ardından Hasköy'de Mahmud Paşa ve Vize medreselerinde müderrislik yaptı. Kanûnî'nin 1552 yılında düzenlediği Nahcıvan seferine de katıldı ve bu sırada sunduğu kasidelerle şöhreti arttı. Sefer dönüşünde sırasıyla Bursa'da Kaplıca ve Hüdâvendigâr medreseleriyle İstanbul'da Atik Ali Paşa, Haseki Sultan Kariye (Hankâh), Haseki Sultan, Sultâniye ve Semâniye medreselerinde müderrislik yaptı. Ardından Şam kadısı ve orada Sultan Süleyman Medresesi müderrisi oldu. 978 yılının Zilkade ayında (Nisan 1571) Şam'da vefat etti. Mezarı Şam'dadır.

Türkçe, Arapça ve Farsça şiirleri bulunan ve devrin büyük âlimleri arasında gösterilen Fevrî'nin, mahlasına uygun olarak çok hızlı ve kolay bir şekilde şiir söyleyebildiği tezkirelerde zikredilir. Gelibolulu Âlî, şiirde atasözleri ve deyimleri kullanmada Necâtî'den sonra Fevrî'nin geldiğini söyler. Özellikle musammatları ile şöhret bulan Fevrî, devrine göre oldukça sade bir dil kullanmıştır. Riyâzî’ye göre Anadolu'da tahmis ve tesdîsi Fevrî meşhur etmiştir. Fevrî, manzum eserler dişında Türkçe ve Arapça mensur eserler de vermiştir. Nesirde devrin klasik üslubuna uygun olarak sanatlı ve secili bir tarza sahiptir. Aynı zamanda devrinin tanınmış hattatlarından da olan Fevrî, Şeyh Hamdullah'ın damadı ve öğrencisi Şükrullah Halîfe'den sülüs ve nesih meşk etmiştir.

\section{Eserleri:}

1. Dîvân: Beyit sayısı 3000'i bulan 50 kadar kaside, 710 gazel, 69 musammat, 41 kıta ve 45 müfretle oldukça hacimli bir eserdir.

2. Risâle fí İlmi'l-Hutût: Hat sanatına ve hattatlık mesleğine dair çeşitli bilgiler ihtiva eder. Müellifin Arapça yazılmış bir hat risalesi daha vardır.

3. Kühl-i Dîde-i A'yân: Manzum kırk hadis tercümesi olup değişik konulara ait hadisler dörder mısralık kıtalar halinde Türkçeye çevrilmiştir. Ayrıca kaleme aldığı bir kırk hadis tercümesi daha vardır.

4. Ahlâk-ı Süleymânî: Kanûnî Sultan Süleyman'ın meziyet ve faziletlerine dair olan eser, Münşeât-ı Süleymânî olarak da bilinir. Secili bir üsluba sahip olan eserde Kanûnî’nin şiirleri açıklanarak onun dünya görüşü anlatılmıştır.

\section{Hac Seyahat-nâmesi: Eser hakkında aşağıda ayrıntılı bilgi verilmiştir.}

Fevrî’nin Tefsîru Sûreti'l-Mülk adlı bir risâlesiyle Risâle-i Kalemiyye ve Risâle-i Seyfiyye gibi bazı Arapça eserleri de vardır. Değişik kaynaklarda Dürerü’l-Hükkâm ile Gurerü’lAhkâm'a ve Beyzâvî'nin Envârü't-Tenzîl adlı tefsirine hâşiyeleri ile Miftâhu'l-Meânî adıyla kaleme aldığı bir Farsça-Türkçe lügatinin olduğu da zikredilmektedir. ${ }^{31}$

\footnotetext{
${ }^{31}$ Fevrî'nin hayatı ve eserleri hakkında birçok tezkire ve biyografik kaynakta bilgi bulunmaktadır. Bu bilgileri tekrar etmemek adına şairin hayatıyla ilgili derli toplu ve son çalışmalardan biri olması hasebiyle Mehmet Kalpaklı'nın Türk Edebiyatı İsimler Sözlüğü’nde şair hakkında yazdıklarını özetleyerek almayı tercih ettik. Daha geniş bilgi için
} 


\subsection{Hac Seyahat-nâmesi}

Fevrî'nin 652 / 1544 yılında hac yolculuğunu anlatmak için kaleme aldığı bu eseri, daha önce Menderes Coşkun Manzum ve Mensur Osmanlı Hac Seyahat-nâmeleri ve Nâbî'nin Tuhfetü'l-Harameyn'i adlı çalışmasında bilgi vererek ilim âlemine tanıtmıştır. Coşkun, ayrıca bu çalışmasında Flügel'in Fevrî̀ye ait olduğunu söylediği ${ }^{32}$ Risâle-i Mekkiyye adlı eserle bu seyahat-nâmenin aynı eser olduğunu belirtmiştir. ${ }^{33}$

Fevrî’nin Hac Seyahat-nâme'si, Süleymaniye Kütüphanesi'nde çeşitli eserleri içinde barındıran bir yazmanın 16b-29b yapraklarında kayıtlıdır. Eserin başında "Risâle fi'l-Menâsik" yazmaktadır. Ancak başıı ile eserin muhtevası birbiriyle uyuşmamaktadır. Coşkun'un da ifade ettiği gibi ${ }^{34}$ bu başlık muhtemelen müellif tarafindan değil de müstensih tarafından konmuş olmalıdır. Eser, kütüphane kayıtlarında da aynı başlıkla edebiyat tarihimizin önemli seyahatnâme türü eserlerinden biri olan Menâzirü'l-Avâlim'in yazarı Trabzonlu Âşık Mehmed'e atfedilmiştir. Eserin Âşık Mehmed'e atfedilmesinin sebebi, Âşık adının metin içinde sıkça geçmesi olmalıdır.

Âşı Çelebi, Meşâ'irü'ş-Şu'arâ adlı tezkiresinde çok yakın arkadaşı olması hasebiyle Fevrî'nin hayatı hakkında ayrıntılı bilgiler verir ve onun hac münasebetiyle çıkmış olduğu seyahatine de değinir. Burada anlatılanlara göre Âşı Çelebi, Fevrî'nin hacca gideceğini öğrenince kıt'a nazım şekliyle 22 beyitlik bir şiir yazar. Bu şiirde Fevrî'ye hitaben çıkacağı yolculuktan kazasız belasız sıhhat içinde geri dönmesi için temennide bulunur ve mağfirete nail olma ümidiyle orada yapacağı dualara kendisini de dâhil etmesini ister:

\section{Ka'be-i kûyına varup yüz urıcak anun Göricek pertevin ol mihr-i cihânârânun \\ Halkaveş ol der-i mihrâbveşe yüz urıcak \\ Vakfede sûz u güdâz ile niyâza turıcak \\ Diyesin kahr ile mihnet-zede bir Âşık var \\ Dürlü mihnetle felâket-zede bir âşıkvâr}

Bundan sonra Âşı Çelebi, Fevrî’nin hacdan dönüşte bir müjdeci vasıtasıyla kendisine bir mektup gönderdiğini ve bu mektubun hülasası olduğunu söyleyerek üzerinde çalıştığımız seyahat-nâmenin giriş bölümü olarak nitelendirilebilecek genişçe bir kısmı birkaç kelime farkı dışında aynen tezkiresine almıştır.

Aşağıda muhteva özelliklerinde de değinileceği üzere Fevrî, seyahat-nâmesine uzunca bir Âşık Çelebi övgüsüyle başlamış ve yine eserin sonunda yirmi beyitlik bir mesneviyle onun övgüsünü yapmıştır. Şair;

\section{Bir ḳuluñ vardur Ilāhì kim adı 'Āşıı kdur \\ Rāh-1 'aşkuñua senüñ gàayet ile șādıḳdur \\ Baña ıșmarladı kapuñda münācāt-1 ḳalem \\ Anuñ içün țapuña keşf-i murādāt-1 ḳalem}

diyerek başladığı bu şiirde hacca çıkmadan önce Âşık’ın kendisine dua etmesini istediğini belirterek Allah’tan ona merhamet etmesini diler.

Fevrî'nin bu şekilde hem eserin başında hem de sonunda Âşık Çelebi'den ayrıntılı bir şekilde bahsetmesi ve Âşık Çelebi'nin hacca gitmeden önce kendisinden duada bulunmasını

bkz. http://teis.yesevi.edu.tr/madde-detay/fevri-ahmed [Erişim Tarihi 15.04. 2020]. Şairin hayatı hakkında bilgi veren eserler ayrıca kaynakçaya eklenmiştir.

${ }^{32}$ Flügel, Gustav, Die Arabischen, Persischen und Türkischen Handschriften Geschichte der Arabischen Litteratur (Supplementband), 3 Cilt, Leiden, 1937-42.

${ }^{33}$ Menderes Coşkun, age., s. 46-49.

${ }^{34}$ Menderes Coşkun, age., s. 46. 
istediğini söyleyerek onun bu talebini yerine getirdiğini açıç̧a belirtmesi, eserin yazılış amacının bu talebin yerine getirilmiş olduğunun muhatabına bildirilmek istenmesi olarak düşünülebilir. Kaldı ki Âşş Çelebi’nin de tezkiresinde Fevrî’nin hac dönüşü kendisine mektup yazdığını söyleyerek mektuptan uzunca bir bölüm paylaşması bu yöndeki iradi durumu teyit eder mahiyettedir.

$\mathrm{Bu}$ durumda eldeki bu eserin Fevrî tarafından Âşık Çelebi'ye gönderilmiş, hac yolculuğundaki maceralarını özetlediği seyahat-nâme tarzında yazılmış bir mektup metni olduğunu söylemek de mümkün görünmektedir.

\subsection{1. Şekil Özellikleri}

Fevrî, Hac Seyahat-nâme'sini, manzum-mensur karışık olmak üzere kaleme almıştır. Eserdeki manzum bölümlerde gazel, mesnevi, kıt'a, terci-i bent ve matla / müfret olmak üzere farklı nazım şekillerini tercih etmiştir. Bu manzum bölümlerdeki toplam beyit sayısı 212'dir.

\subsubsection{Muhteva Özellikleri}

Seyahat-nâme'sine muhatabı Âşık Çelebi'yi överek başlayan Fevrî, bu amaçla manzum ve mensur olarak Âşı Çelebi'nin sahip olduğu vasıfları ayrıntılarıyla tavsif eder. Şaire göre Hz. Peygamber soyundan gelen Âşık Çelebi, akli ilimlerde Seyyid-i Sânî, naklî ilimlerde Sa'd-1 Taftazânî, nahiv ve sarf ilminde Sibeveyh, Ahfeş ve Ferrâ; mantıkta İbn-i Sînâ'dır. Mana ve beyanda Sehbân-1 Vâil, aruzda Halil, tefsirde Kâşânî ve Allâme, hadiste ise Müslim ve Buhârî' dir. İnşada Harîrî, gönül açıcı şiirleriyle de Ferezdak ve Carîrî'dir. Matematikte zamanın Öklidis'i, astronomide Batlamyus, tarihte Taberî ve İbn-i Hallikan, lügat ilminde Cevherî, dinî ilimlerde ise Ebu Hanife, Yafii, İmam Malik ve Şafii' dir. Âşık Çelebi hakkındaki övgü dolu bu ifadelerden sonra Fevrî, onun nazım ve nesirde sahip olduğu kabiliyetleri on beyitlik bir kıt'ayla ayrıca dile getirir.

Âş1k Çelebi'nin bu uzunca övgüsünden sonra şair, asıl konuya geçer. 952 yılının Rebiülevvel ayının 9. gününde (21 Mayıs 1545) gemiyle yola çıkar. Önce Gelibolu'ya, ardından Rodos üzerinden Misır'a geçer. 31 günlük deniz ve kara yolculuğundan sonra Kâbe'ye ulaşır. Fevrî, bu seyahat esnasında yol güzergâhındaki yerleşim yerlerinde bulunan Yazıcızade Muhammed, Şeyh San'an ve Hazret-i Danyal gibi önemli kişilerin mezar ve türbelerini ziyaret etmekle kalmaz; aynı zamanda buralarda hayatta olan âlim ve fazıl kişileri de ziyaret halkasına dâhil eder.

Aynı yılın Receb ayının 8. gününde (15 Eylül 1545) dua ve salavatlarla Mescid-i Haram'a girer. Şair, Beytullah'a karşı beslediği sevgiyi ve içinde bulunduğu his yoğunluğunu on beyitlik Kâbe redifli bir gazelle dile getirir. Aynı yılın Şevval ayının ortalarına kadar Mekke'de kalarak safa ve umre yapar. Buradaki vakitlerini ibadet ederek ve bazı ilim adamlarının sohbetlerine iştirak etmek suretiyle değerlendirir.

Buradan Peygamberimizin kabrini ziyaret etmek için Medine'ye gelen şair, bir ay sonraki Mısır ve Şam hacı kervanlarının gelişine kadarki zaman zarfında burada kalır. Kervanların gelmesiyle birlikte hac yapmak için kervanlara iştirak eder ve Mekke'ye gelir. Hac vazifesini ifa edip Zilhicce ayının 26'sına kadar tespih, dua, umre ve safa yaparak vaktini değerlendirir. 27 Zilhicce 952 (1 Mart 1546) tarihinde tekrar Medine'ye gitmek üzere sefere çıar. Şair buradan ayrılmış olmanın teessürünü beş bentlik bir terci-i bentle dile getirir. Medine güzergâhındaki menzillerde bulunan eserler ile Bedir ve Huneyn savaşlarında şehit düşenlerin kabirlerini ziyaret ederek 7 Muharrem 953 (10 Mart 1546) tarihinde sabah vakti Medine'ye ulaşır. Buraya vasıl olmanın mutluluğunu bir gazelle dile getirerek Peygamber Efendimizin mezarını ziyaret eder ve üç güne yakın burada vakit geçirir.

10 Muharrem 953'te (13 Mart 1546) Şam kervanına katılarak dönüş için sefere çıkar. T1pk1 gelişte olduğu gibi dönüş yolculuğunda da güzergâhtaki ulu kişilerin makamları ziyaret edilerek Kudüs'e varılır. Hama ve Humus üzerinden Şam'a ulaşan Fevrî, Şam ve civarında 
bulunan Veysel Karenî, Bilal-i Habeşî ve Muhyiddin Arabî gibi birçok âlim ve din büyügünün kabirlerini ziyaret eder.

Şair buradan sonra tekrar hac esnasında Arafat'ta vakfede şahit olduğu manzarayı resmetmeye başlar. Bu öyle bir manzaradır ki Allah'ın mağfiret ve merhametine muntazır olan müminler, Kâbe etrafını coşku ile doldurmuş, bütün dünya gailelerinden el çekmiş bir hâlde feryat ve figanlar içinde rablerine tazim içindedirler. Allah Allah ve lebbeyk nidaları adeta gökyüzünü inletmekte, yıldırım gürültülerini andıran bu sedalar Kahire'deki Ezher Camii'nde ve Kudüs'teki Mescid-i Aksa'da yankılanmakla kalmayıp Sidretü'l-Münteha'ya erişmektedir.

Fevrî, Kâbe'deki müminlerin içinde bulundukları hâllerin tasvirini tamamladıktan sonra ikişer beyitle dönemin padişahı Kanuni Sultan Süleyman, vezirler, valiler, âlimler, fazıl kişiler, kadılar, şeyhler, salihler, fakirler, zahitler, ilim talebeleri, şairler ve zarifler için hayır duada bulunarak bu saydığı kişilerin emellerine nail olmaları için Allah'a niyazda bulunur. Daha sonra yirmi beyitlik bir mesneviyle Âşık Çelebi'nin övgüsünü yapar. Şair;

\section{Baña ıșmarladı ḳapuñda münācāt-1 ḳalem \\ Anuñ içün țapuña keşf-i murādāt-1 ḳalem}

diyerek Âşık Çelebi’nin hacca çıkmadan önce kendisinden dua 1smarladığını ifade ederek yapmış olduğu bu övgünün amacını da dile getirerek eserini tamamlar.

\subsubsection{Dil ve Üslup Özellikleri}

16. yüzyılın önde gelen şairleri arasında gösterilen Fevrî, sadece manzum metinler yazan bir sanatkâr olmamış aynı zamanda yazmış olduğu mensur eserlerle de temayüz etmesini bilmiştir. Şairin nesir alanındaki başarısını tescil eden eserlerden biri de manzum-mensur karışık tertip ettiği Hac Seyahat-nâmesi'dir.

Fevrî, yolculuk izlenimlerini anlattığı seyahat-nâmesinde oldukça tumturaklı bir üslup kullanmıştır. Eserdeki nesir parçaları âlî üslubun bütün özelliklerini taşır. Şairin üslubu özellikle Arafat, Kâbe ve Ravza-i Mutahhara gibi kutsal mekânların tasvirinde ve Âşık Çelebi'nin övgüsünün yapıldığı manzum ve mensur bölümlerinde daha da sanatkârâne bir vaziyet alır. Manzum parçalar genel itibarıyla nesir bölümlerine göre daha sade ve anlaşıllır bir dille kaleme alınmıştır. $^{35}$

Fevrî’nin dinî ilimlere ve Arapçaya olan vukufu hususunda kaynaklar fikir birliği içindedir. Özellikle yakın arkadaşı Âşık Çelebi onun bu özelliği üzerinde uzun uzadıya durur. ${ }^{36}$ Şairin Seyahat-nâme'sinde kullandığı dil, kavram ve terimler dinî ilimlere ve Arapçaya vâkıf biri olduğunu fazlasıyla hissettirecek niteliktedir. Bilhassa olayların akışına, yaptığı tasvir ve açıklamalara mütenasip olarak iktibas yoluyla kullandığı otuz civarındaki ayet, hadis ve bazı Arapça kelam-1 kibarlar bunun en güzel delilidir.

Aynı şekilde şair, serdettiği düşünce ve tasvirleri desteklemek amacıyla sıkça manzum metin kullanmayı tercih etmiştir. Manzum parçaların dikkatleri çeken en bariz özelliği, samimi bir edayla ve lirik bir tarzda tanzim edilmiş olmalarıdır. Yukarıda da zikredildiği gibi bu manzum parçalar mensur bölümlere göre daha sade bir dile sahiptir.

\section{Nüsha Tavsifi}

Fevrî’nin Hac Seyahat-nâme'si, Süleymaniye Kütüphanesi Şehid Ali Paşa Koleksiyonu'nda 2828/3 arşiv numarasıyla "Risâle fi'l-Menâsik" başlığıyla kayıtlıdır. Büyük çoğunluğu dinî eserlerden oluşan bir risale mecmuasının 16b-29b sayfalarında yer alan eser,

\footnotetext{
${ }^{35}$ Menderes Coşkun, age., s. 49.

36 Filiz Kılıç, Meşấirü'ş-Şu'arâ, Kültür ve Turizm Bakanlığ1 Yay., Ankara 2018, e-kitap: http://ekitap.kulturturizm.gov.tr/Eklenti/59036,asik-celebi-mesairus-suarapdf.pdf?0, [Erişim Tarihi: 01.02.2019]. s. 531-33.
} 
manzum-mensur karışık bir şekilde; her sayfada 19 satır hâlinde ve talik hatla kaleme alınmıştır. İstinsah tarihi ve müstensihi hakkında herhangi bir kayıt bulunmamaktadır.

\section{Metin}

\section{Risāle fi'l-Menāsik}

fe'ilātün fe'ilātün fe'ilün

1. Ey gül-i ravża-i gülzār-1 neseb

Semen-i bāģçe-i fażl u edeb

2. Gonce-i gülbün-i bāg̀-1 Nebevī

Bülbül-i tāze-gül-i Muștafavī

3. Lem`a-i şem`a-i envār-1 Hुudā

Şu' le-i meş ale-i rāh-1 Hüdā

4. 'Umde-i zümre-i evlād-1 Nebī

Zübde-i āl-i Resūl-i 'Arabì

5. Der-i dürc-i yem-i ālāy-1 Resūl

Dürr-i burc-1 dür-i zevcā-yı Betūl

6. Seyyid-i zümre-i sādāt-1 i' zaām

Eşref-i țầ 'ife-i āl-i kirām

7. Şemª $a-i$ şehr-i ma'ārif-i ' Ali

Mıșra'-1 bāb-1 'ulūm-1 Nebevī

8. Nūr-1 mihr-i felek-i ḳadr u şeref

Dürr-i pāk-i șadef-i şāh-1 Necef

9. Kațre-i şeb-nem-i bā'ge-1 Kureşi

Burc-1 'izzetde sa' ādet güneşi

10. Server-i taht-1 ekālīm-i sühan

Hüsrev-i memleket ü naẓm-1 Ḥasen

11. 'Alevi vü Kureşi Muțalibi

Seyyidi ya'ni [ki] 'Āşsk Çelebi

12. Dür-i deryā-yı nübüvvet ' Āşṣ

Mevc-i ' ummān-1 fütüvvet ' $\bar{A} s ̧ 1 k$

13. Kevkeb-i çarh̆-1 risālet sensin

Kamer-i burc-1 siyādet sensin

Ey hakāāyıkşsinās-1 mesā 'il-i evrāḳ-1 bì-şümār-1 meẓāhir-i ḳāf u nūn. V'ey deḳā 'iḳ-güşā-y1 resā' 'il-i eṭbāḳ-1 zer-nigār-1 defātir-i çarḩ-1 būḳalemūn. Ey nāẓım-1 dürer-i gurer ü silk-i me āní-i ferhunde-me āni ki lem yațiṣhünne insün ḳablehüm velā cānnun ${ }^{37}$ andan bir beyāndur. V'ey rāḳım-1 cevāhir-i samṭ-1 beyān-1 rengīn tibyān ki ke 'ennehünne'l-yāḳütu ve'l-mercānn ${ }^{38}$ andan bir nişāndur. Ey mübdi -i bedāyic -i ezhār-1 besātīn-i feșāḥat ki rüsümāt-1 ḳaṭarāt-1 emțār-1 gamām-1 aḳlām-1 dürer-bārı ile șaḥn-1 ravża-i gülşen-i inşā muhażżar u müzehher. Ve’y (17a) bāğbān-1

\footnotetext{
37 “Onlara, önce ne bir insan ne bir cin dokunmuştur.” Rahman Suresi, 74. ayet.

38 "Onlar sanki yakut ve mercandır.” Rahman Suresi, 58. ayet.
} 
gülistān-1 reyāḥin-i belāgat ki nefehāât-1 nesemāt-1 esrār-1 kelām-1 pür-intizāam-1 ' anber-niṣār ile bāģçe-i şi r r-i dil-güşā mu' aț̣ar u münevverdür. Naẓm:

\section{fe'ilātün mefā'ilün fe'ilün}

1. Ey serīr-i kiyāsetüñ şāhı

Vey sipihr-i dirāyetüñ māhı

2. Ey nihāl-i riyāż-1 'ilm ü kemāl

V'ey hilāl-i sipihr-i ‘ izz ü celāl

3. Ey vahịid-i zamān ferìd-i cihān

Menba $^{`}-1$ fażl [ü] ma` den-i 'irfān

4. Fāżıl u kāmil ü vahịib ü nesīb

' Ālim ü ‘ āmil ü edīb ü erīb

5. Taḩtgāh-1 siyādete sultạan

Mülk-i fehm ü firāsete hāạān

6. ' Iİlm ü hikmet diyārı Loḳmānī

Fażl u rütbede Seyyid-i sānī

7. Fuṣahāà haylinüñ ser-efrāzı

Bülegāanuñ emīi ü mümtāzı

8. Meclis-i ehl-i naẓm-1 Ḥassāni

Maḥfel-i hyayl-i neșr-i sübḥānī

9. Ma` den-i 'ilm-i zāhir ü bāṭın

Künc-i ‘ ạ̣l u rivāyete huāzin

10. Efụal-i dehr ü efșaḥ-1 fuṣaḥā

Ekmel-i ' așr u eş ar-1 şu' arā

11. Șūretiyle çü Yūsuf-1 Ken 'ān

Sïret ile şebīh-i fahr-1 cihān

Bugün sen ol cevān-1 nüktedān-1 zūu-fünūn u engüşt-nümā-y1 fużalā-yı fuṣahāà-y1 gerdūnsın ki 'ilm-i ma' ḳūātda Seyyid-i sāāi vü fehm-i menḳūātda Sa'd-1 Taftazāni ' ulūm-1

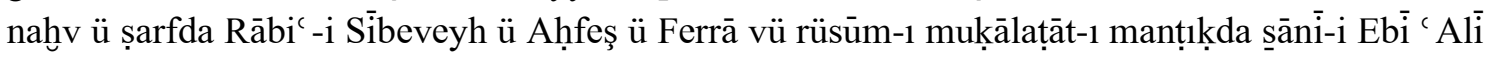
bin Sinā envā' -1 hikemiyyātda mu'allim-i șālis ü aṣnāf-1 ilāhiyyātda üstād-1 mu' allim-i evvel dinilse revā. Ādāb-1 ma ānì vü beyānda Saḥbān-1 Vā'ill[ī] ve buhūr-1 'arūżda Hulîil-āsā baḥr-1 sā 'il ḥaḳāyıḳ-1 lețā'if-i tefāsīr-i şerīfede Kạşānī ve 'Allāmeden nişān ve deḳā'iḳ-i şerā 'if-i eḥādīis-i (17b) münífede Müslim ü Buhārī gibi șahịụ̈’l-beyān. Rumūz-1 maḳāmāt-1 inşāda Bedī' ü'z-zamān u Harīīi ve künūz-1 hayāāāt-1 eş‘ ār-1 dil-güşāda cihānuñ Ferezdāk u Cerīīi. Eşkāl-i hendesiyyede Öḳlīīis-i rūzigār u evżă $\bar{c}^{-1}$ hey'eviyyede Baṭlamyus-1 dār u diyār. Hikāyāt-1 tevārihhde Ṭaberī ve İbn Hualliḳān ve rivāyāt-1 lugāatuñ ḳamusında Cevherīi deverān.

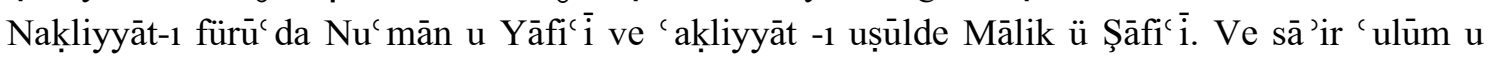
rusūmda eger mensūur eger manzūumda naẓm:

fe'ilātün fe`ilātün fe`ilün

1. Kalemüñ Ḣiżr u midāduñ zulemāt

Kelimātuñ dükeli āb-1 ḥayāt

2. 'Aḳl-1 evvelsin ü sırra maḥrem

Elüñ altında durur levḥ ü ḳalem 
3. Manț1ḳuñ hịkmet ile baḥr-1 revān

Sözlerüñ cümle me ānì vü beyān

4. Her hadīsi ki muhịt ola żamìr

Bir kelāmuñ ḳ1lur anı tefsīr

5. Nāṭ̂kuñ genc-i süh̆an miftāḥı

'Āḳilüñ genc-i zalam miṣbāḥı

6. Ḩāmeñe n'ola disem İskender

Garb ile şarḳa degin hükm eyler

7. Ya disem aña n'ola Zü'l-ḳarneyn

Baḥr ile berre virür zinet ü zeyn

8. Tab`uñuñ baḥrı ma`āni pürdür

Her sözüñ anuñ içün bir dürdür

9. ' İlm ile halk-1 cihān fahr eyler

Faḩr ider zāâtuñ ile fażl u hüner

10. Āb-1 'ilm ile muhammer 'Āşı

Nūr-1 fażl ile münevver 'Āşı̣

11. Kime kim șan' at ise fażl-1 hasen

Saña mīīāśdur eb [ü] cedden

Belki sen ol 'Āşık-1 șādıḳ-1 'ālī-miḳdār-1 pür-iftihārsın ki şol mālik-i memālik-i maḥabbet ü serdār-1 dār u diyār-1 meveddet. Şāh-1 ḥālet-bahş̧-1 efrād-1 'ālemīn ve (18a) pādişāh-1 salțanatrān-1 semāvāt u arżı̀n naẓm:

mefācīlün mefăcìlün fe'ūlün

Maḥabbet milketinüñ pādişāhı

$\mathrm{Sa} a^{\mathrm{a}}$ det çarhınuñ ferhunde māhı

olup mecmū'-1 'ulviyyāta hü̈km-i cihān-muțāe nn tābı nār-1 pür-şerārvār sārì ve 'āmme-i süfliyyāta emr-i vācibü’l-ittibā'`1 seyl-āb-1 seḥāb-1 bahār-1 medār gibi cārīdür. Naẓm:

fe`ilātün mefā‘ilün fe`ilün

1. Rāmdur hükkmine zemīn ü zamān

Mūmdur emrine mekīn ü mekān

2. Aña muhtācdur ganī vü faḳir

Aña tābi` dürür emīr ü esìr

3. Anuñ ile țurur bu seb` u cihār

Leyse fi'd-dāri gayruhu deyyār ${ }^{39}$

sūz-1 iştiyāḳ-1 'āşıḳan-1 Dehlevī anuñ zebāne-i pür-sūzından bir 'alev ve tāb-1 iftirāḳ-1 müşteḳān-1 Pehlevi anuñ sūz-1 dil-fürūzından bir pertevdür. Naẓm:

fe'ilätün mefä‘ilün fe'ilün

1. Kaysı Mecnūn ider odur ammā

Ara yirde bahānedür Leylā

39 "Evde ev sahibinden başka kimse yoktur." 
2. Vāmıḳa andan irmese vāye Baḳmaz idi ' ižār-1 'Ažrāya

3. Sūz u şevḳ ile olmadın üstād Cān-1 Şīinini virmedi Ferhād

Külliyen besābiț-i müzāhirüñ izdivācı anuñ rābıțasıyla ve cemíc 'i mürekkebāt-1 ' anāṣıruñ imtizācı anuñ vāsıṭasıyla belki nüfūs-1 mücerredenüñ ecsām-1 enāma ta' alluḳ ve vuṣūi anuñ bendiyle ve ervāḥ-1 muḳaddesenüñ esbāḥ-1 hâṣ u 'āma duhūl ü hulūli anuñ peyvendiyledür. Beyt:

mefă‘ilün fe`ilātün mefā‘ilün fe`ilün

Şeh-i zemīn ü zamāndur Hudā penāhıdur

Felek muṭị ü cihān hualḳı hāk-i rāhıdur

'Āşıklaruñ şevk ü żevḳ-i mahabbet ile ibtihācı anuñ zaātından șudūr ve ma'şūḳlaruñ hüsn ü zinet ü lețāfetle revācı anuñ lețāfet-i șıfātından zuhūr buldugì ecilden gāh 'uluvv-i şānına vü sümüvv-i mekānına mag̉rūr olup beyt: (18b)

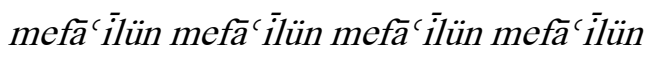

Ben ol mihrem ki hurş̧ìd-i cihān bir zeerredür benden

Ben ol bāgaam ki Ṭūbā şāḩı berg-i terredür benden

diyü mütebaḥhiri ü mütebessim ü gāh ahāli kevn ü mekāna vü e āli zemīn ü zamāna fermānınuñ cereyānına mesrūr olup beyt:

\section{mefā'ilün fe'ilātün mefā'ilün fe'ilün}

Menem ki Hुüsrev ü Mecnūn mekīn gulām-1 menet

Menem ki Leyli vü Şīīin esīir-i dām-1 menet

beytiyle mütekellim ü müterennim olan sālār-1 nāmdār-1 ḩıț̣-gūn u fesād u şehriyār-1 büzürgvār

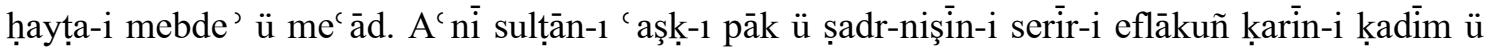
hem-nişin ü nedīmi belki bir vech ile refî̀ ü şefīk ve celis ü enisisin ki 'ilme'l-yakịinden geçüp

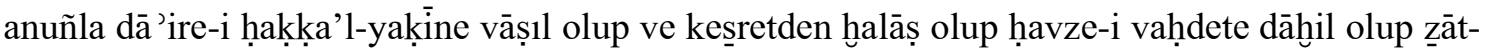
1 şerifi ve 'unșur-1 lațifi ile birlige baḳup ve kemāl-i ittihādda bir mertebeye baḳup durursın ki beyt:

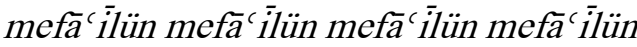

Egerçi nām-1 'Āşık ismine ' aşḳuñ muḡāyirdür

Velī zāât u șıfăta nāẓır olsañ ikisi birdür

Maḳāmın bulup sen dahi anuñ cemíc aḥkām u evșāf ile muttaṣıf vücūdın 'ārıżeyn-i hatțịide farḳuñuz bir elif olup ol dahi ekșer iḥtimāl yā nihāl-i cism-i nizār-1 'Āşıḳdan dỉde-i remed di்delerde ḳalmış ḩayāldür. Veyā 'āşı̣̂-1 șādıḳuñ 'aşkẹ-1 pāk ile birligine dāl ola diyü vaż olınmış bir hāldür. Veyā eșer-i dūd-1 āh-1 dil-i pür-vecd ü hạāl-i ' āşıḳdan müteşemmil olmış bir timșāldür. Ol cānibde aḥvāl bu minvāl ü bu şikeste-bāl ü haste-ḥālde zebān-1 kefüñ delāl ile ol zāât-1 melek-ḩıșālüñ medḥ ü tavșífin ve taḥsin ü ta' rifin kemā yenba' $i^{\overline{4}}{ }^{0}$ edā eylemege mecāl

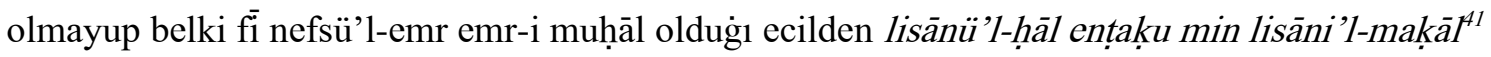
diyüp tekellüf-i medh ü ițrādan ve te assüf-i şi $\mathrm{r}$ ü inşādan etkiyā' '-i ümmeti büreā 'ü mine'ttekellüf $f^{42}$ muḳteżāsınca ferāgat olunup bì-nihāye ed iyye-i țayyibe Resūl-i nesīm-i Mekke (19a)

\footnotetext{
40 "İcap ettiği gibi."

41 "Hâl sözü, dilin sözünden daha doğrudur."

42 "Ümmetimin takvalıları aşırıya gitmeden beridirler / uzaktırlar."
} 
vü țayyibe ile ve eșniye-i vācibü'l-ḳabūl baña ve șabā-yı Medīne-i Resūl ile șalla'llāhu 'aleyhi vesellem ol ḥarem-i muhterem ḳıble-i āmāl ü rükn-i mu'aẓam Ka'be-i iclāle ki fi'l-ḥaḳiḳa feżā-yı șaḥn-1 Ka' be-i ' ulyā vü șaḥrā-yı memālik-i Yeșrib ü Baṭ̣ā gibi mațlab-1 a' lā-yı ḩāṣ u 'ām u maḳṣad-1 akṣā-yı efāżıl-ı enāmdur. İtḥāf u ihdā ḳılınduḳdan ṣoñra inhā-i müsāfir-i țariḳ-i Ḥicāz ve enbār-1 mücāvir-i Ka' be-i niyāz ma rūż-1 zāyir-i ḩāk-i pāk-i ḥarīm-i ḥarem-i Nebevì ve merfü '-1 nāẓır-1 meșvā-yı pür-nūr-1 tābnāk-i Muștafavī budur ki eger luṭf-1 'amīm ü kerem

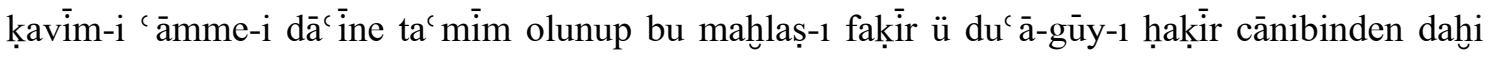
istihbār olunmaḳ cā'iz ise bidāyet-i icmāl-i hạâl ve nihāyet-i tafșill-i māfi'l-bāl budur ki biḥamdi'llāhi ve'l-minne ${ }^{43}$ Allāhu Te $e^{c}$ àlā celle ve 'alānuñ ' ināyetiyle ve yārān-1 bā-șafānuñ șafāyı himmet-i ' āliyeleri berekātiyle sene 952 rebī' ü'l-evvelinüñ 9 güninde maḥrūse-i İstānbūldan bismi'llāhi mecrāhā ve mürsāhā diyüp rākib oldug̉umuz fülk-i felek-misāa ü cöng-i Kaāftims̄ālüñ yolı Gelibolıya ugrayup mü'ellif-i kitāb-1 Muḥammediye olan Yazıcı-zādeyi vü Rodos-1 sa ādet-me'nūsda vāḳı c olan şühedā-yı mü 'minīn ve guzāt-1 muvaḥhidīni ve bender-i İskenderde maḳarr-1 evliyā ve müstaḳarr-1 aṣfiyā merḳad-i Şeyh Șan`ān-1 pür-ḥāl ve meşhed-i Hażret-i Dānyāli 'azm ü bilād-1 Reşid ü Mıșriyyede olan 'ulemā-i dīn ü e'imme-i müctehidīnsīmā Ḳırāfa nām maḳām-1 pür-ihtirāmda ki mecma' -1 akțāb u efrād u müctemi' -i kümmel ü āhāddur āsūde olan İbn-i Fāriż ü enām-1 Şāfi ‘ $\bar{i}$ vü șahābe vü tābi ỉnden dīn-i İslāmuñ mu in ü nāfí i olan e ’imme-i dīn ü ecille-i ehl-i yaḳini ve şehr-i Süveysde mānend-i Üveys ü Șahīb olan Şeyh Garīibi ve diyār-1 Ṭürda ve sevāḥil-i baḥr-1 mescūrda sāe $\bar{i}$ (19b) Yaḥyāyı vü merāèn Ḥażret-i Mūsāyı vü bilād-ı Kuṣayr u Cidde vü Ḥaddede olan cemíc evliyā vü etḳiyāyı ḥattā serāyı Ḥażret-i Ḥavvāyı vü meșvā-yı ümmü ümmühāt-1 verāyı ziyāret ü diyār-1 mezbūrede bi’1-fi`‘ 1 kayd-1 hayātda sākin ü dünyā-yı bì-ṣebātda mütemekkin olan efāżıl u ahālí muvānesetiyle ve meşāyih ü mevāli mușāḥabetiyle istifāde-i ma ārif-i cemíle vü taḥṣil ü tekmîl-i ' avārif-i cezīle iderek müddet-i sefer-i baḥr u berr ü zamān-1 țayy-1 țarik havf u haț̣ otuz bir gün olınca naẓm:

Fì-Șifat-1 $\mathrm{Ka}^{\mathrm{c}}$ be

fe'ilātün fe'ilātün fe`ilün

1. Mevlid-i Ḥażret-i Sulțān-1 rüsül

Mesken-i server-i aṣhāâb-1 sübül

2. Menbit-i serv-i riyāż-1 ceberūt

Menşe'-i gülbün-i bāg̀-1 melekūt

3. Kụble-i şāh u halḳ-1 'ālem

Ka'be-i rāh-nümā-yı Ādem

4. Maṭla ${ }^{c}-1$ mihr-i Hirā-yı devrān

Menba' -1 çeşme-i 'irfān-1 cihān

5. Ḥarem-i muḥterem-i Sübḥānī

Gülsitān-1 İrem-i insānī

6. Meş ar-1 Ḥażret-i Yezdān-1 ḳadīm

Manẓar-1 'ayn-1 ' ināyāṭ-1 kerīm

7. Mehbiț-i pertev-i envār-1 Hüdā

Menzil-i mā'ide-i luṭf u 'aṭā

43 "Hamd ve minnet Allah'a mahsustur." 
8. H Hāl-i ruhsāre-i iḳlīm-i cihān

Noḳtạ-i dā ire-i kevn ü mekān

9. Merdüm-i dīde-i a ' yān-1 vücūd

Naṣb-1 ' ayn-1 naẓar-1 ehl-i şühūd

10. Melce'-i ehl-i ma āṣi vü ḳusuur

Me'men-i țāi ife-i zenb ü fütūr

11. Mațlab u makṣad-1 aṣhāāb-1 niyāz

Merci' -i 'āzim-i iḳlīm-i Ḥicāz

A`ni Mekke-i müşerrefe serḥaddine beyt:

fe'ilātün fe'ilātün fe'ilātün fe'ilün

Ten libāsın çıkarup ' umre șafādur diyü cān

Ka'be-i kūyına 'azm eyledi lebbeyk-künān

Beytini vird-i zebān u naḳl-i lisān idüp (20a) iḥrām-1 pāk ü neş 'e-i müdāme-i şevḳ ile feraḥnāk naẓm:

\section{fe'ilātün mefā'ilün fe'ilün}

1. Merve haḳḳı girüp șafã buldum

Dil-i bīmāruma devā buldum

2. Huste idüm belā-yı hicr ile

Vașla irdüm o dem şifă buldum

3. Altun itdüm işüm bi-ḥamdi'llāh

Cevher-i pāk-i kỉmyā buldum

Sene-i mezbūrenüñ māh-1 recebü'l-müreccebinüñ sekizinci gicesinde zamān-1 tezkīir ü

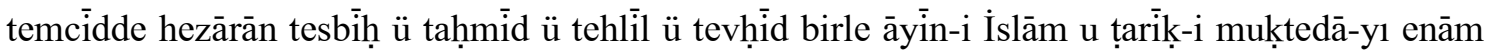
'aleyhi'ṣ-șalavāt ü ve's-selām üzre bāb-1 selāmdan harīm-i Beytü'l-ḥareme bi'smi'llāhü'lmelikü'l-'allāmü ve'ṣ-șalavāt 'alā efżalü'l-enām ${ }^{44}$ diyüp ḳadem-i ihtimām baṣduḳda nā-gāh fetīl-i bisyār-1 tābdār arasından ve ḳanādìl-i encüm-şümār-1 pür-envār māverāsından beyt-i şerifi şeref-fezā vü hāne-i münif-i dil-güşā vü ferah-bahşā verā-yı hicāb-1 sehābda pinhān olmış ḳurṣ-1 māh-tāb-1 şeb-efrūz-1 nūr-efşān u libās-1 zalām-1 leyle-i miskīn-fāmda kendüye sāyebān itmiş cirm-i āfitāb rūz-1 pīrūz-1 dırahş̧ān gibi siyāh cāmesinüñ beḳāsından ve kisvet-i ' anbersāsınuñ māverāsından pertev-i envār-1 hidāyet ü leme' āt-1 iş ${ }^{c} a-i$ sa' ādet ile şāriḳ ü bāriḳ ü zāhir ü bāhir olıcaḳ dīde-i 'aḳl-1 bārīk tārik olup idrākden 'āciz ü ḳāṣır u dil-i lā-ya' ḳıl nice zamān mütehayyir ü müte' akkir țurup ba'd-1 zamān fi'l-cümle 'aḳl-1 vuhūş yār u ser-mesken hüşyār olıcak evvelā hezār sūz u güdāz u tażarru' u niyāz ile hițāb-1 müstețāb idüp naẓm:

\section{fe'ilātün fe'ilātün fe'ilātün fe'ilün}

1. Ey günehkārlara makșad-1 Akșā Ka' be

Ey siyehkārlara mațlab-1 à lā Kac be

2. Ey ḳapuñ mațlac -1 envār-1 Hudū celle celāl

Huil' atuñ mag̉rib-i mihr-i felek-ārā $\mathrm{Ka}^{`}$ be

3. Ey șafâ țâlibine menzil ü mesken ḳıble

Ey güneh hāribine melce vü me 'vā $\mathrm{Ka}^{c}$ be

\footnotetext{
44 "Her şeyin sahibi ve her şeyi bilenin adıyla (başlarım), mahlukâtın en üstününe salat olsun."
} 
(20b)

4. Menzil-i raḥmet-i Ḥaḳ mehbiț-i envār-1 Hudāā

Ḥaremüñ feyż-dih-i mescid-i Akșā Ka ${ }^{c}$ be

5. Aṭlas-1 çarh senüñ cāmeñe nisbet ḳara şāl

Ey siyeh-pūş olan kisveti zỉbā $\mathrm{Ka}^{\mathrm{c}}$ be

6. Saṭhuñuñ şemsesi sāye-fiken-i ' arş-1 berīn

Ferşüñüñ ḥoḳkası eflākden a' lā Ka' be

7. Ey cihāndan kesilüp zāhid-i Ḥak gibi çeken

Hurḳaya başını vü dāmenine ya $\mathrm{Ka}^{`}$ be

8. Haste-dil işigüñe gelmege buldı şifã

Ey cemālüñ dükeli derde müdāvā $\mathrm{Ka}^{c}$ be

9. Şol ḳadar ḳadr vire saña Hudā kim ebedī

Baş ḳoya işigüñe cennet-i 'ulyā $\mathrm{Ka}^{`}$ be

10. İşigüñ tozına yüz sürmege geldi Fevrī

Anı redd itme ḳabūl eyle meded yā $\mathrm{Ka}^{c}$ be

diyüp ba' de āheste āheste ḥayret ü gayretle iḳdām u ihtimām idüp erkān u ādāb 'umre temām edā olmağla 'umre vü șafā virüp dem-i mezbūrdan evāsıț-1 şevvāle dek Mekke-i müşerrefede gāh sa'y ü gāh țavāf [u] i' tikāf gāh 'ibādet ü țā'at-i zü̉'l-celāl ü gāh muṣāḥabet-i muvāneset-i erbāb-1 fażl u kemāl ile iştiḡāl üzre olındı. Naẓm:

\section{fe'ilātün fe'ilātün fe'ilün}

1. $B a^{c}$ dehu maḩzen-i gencine-i din

Ma' den-i cevher-i esrār-1 yakịin

2. Ravża-i pāk-i gül [ü] gülbün-i cūd

Gülşen-i nāza gül-i bāğ-1 vücūd

3. Mațlac -1 mihr-i Hirā-yı șaḳaleyn

Mağrib-i māh-1 emān-1 kevneyn

4. Mehbiț-i nūr-1 serā-perde-i zāāt

Menzil-i mihr-i tecellì-i șıfăt

5. Menba ${ }^{\complement}-1$ çeşme-i esrār-1 hüdā

Meş'al-i pertev-i envār-1 Hुudā

6. Meşhed-i māh-1 nübüvvet ya' nì

Merḳad-i şāh-1 fütüvvet ya'ni

7. Kulzüm-i dürr-i yetīm-i Nebevī

Burc-1 dürrīi rūḥ̂-1 Muștafavi

8. Kūy-1 gūyā-yı rü 'yet-i Rabbì

A'ni meșvā-yı Nebiyy-i 'Arabī

(21a) 'aleyhi'ṣ-ṣalātü ve's-selām ki fi'l-ḥaḳiḳa mehbiṭ ü menzil-i mücerrede-i melā'ik ü mecma` u maḥfel-i nüfüs-1 muḳaddese-i mütteki' iñe ${ }^{45}$ 'ale'l-erā 'ik belki mețāf u mezār-1 ehād cemìi ins ü cān u merkez ü medār aḳțāb u efrād mecmū' -1 kevn ü mekāndur. Ḥattā ay ve güneş felekler hep üstine dönerler

45 “(Orada) koltuklara uzanırlar.” İnsân Suresi, 13. ayet. 
ve ba' $\dot{z}-1$ ' ulemā-y1 'iẓām ü fużalā-yı kirām dahi inne ziyāreti nebiyyinā 'aleyhi's-selām ü ve'ṣ-ṣalavāt

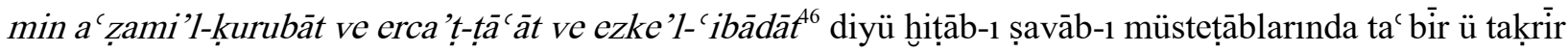
ve ba ż-1 aṣhāb-1 dīn ü e āli erbāb-1 yaḳin min efżali'l-müstehabbāt ve'l-mendūb bel-yakrubu min dereceti'l-vücūb ${ }^{47}$ diyü ebvāb-1 kitāb miskīn-niḳāblarında tahrīir ü tasțiir buyurmışlardur. Ve ahbār-1

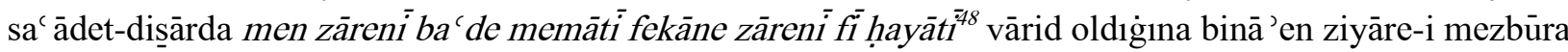

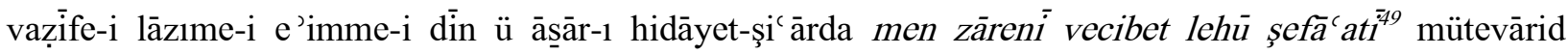
olduğına i' tinā' $-i$ aḥyānā ol cānibe müsāferet ḳā'ide-i muḳarrere ecille ehl-i yaḳin olmag̀ın kemīne-i dirīne dahi hengām-1 būm-1 ma' lūmda 'idād-1 ḳavm-i merḳūmdan maḥsūb u ma' dūd olmaḳ recāsıyla ' inān-1 'azìmet-i semend-i himmeti Medīne-i Münevvere ve Ravża-i Muțahhara semtine mașrūf u ma țūf ḳılup ārzū-yı hususūl-i murādāt u temennì ḳabūl aṣnāf-1 hạāât ile 'azm-i sefer-i ẓafer rehber eyledüm. Elḥamdu-li’llāh eymen-i evḳāt u eşref-i sā' at ve hüün-i ḩālātda ziyāret-i hāāk-i pāk-i harāim-i ḥarem-i muḥterem seyyid-i enbiyā ve naẓar-1 meșvā-yı tābnāk ü cūd-1 şerif sened-i evliyā a' nì Muḥammed Muștafâ șalla'lāhu ' aleyhim müyesser olup berā-yı miḳdār-1 hāk-nişīn-i rāh-1 kūy-1 habīb ile 'uzlet-güzīni gūşe-i ḥarem-i sa ādet-i destgāh olup tā huuccāc-1 Miṣr u Şām u revāḥil-i ḳavāfilli sa ādet-fercām (21b) gelüp geçince eger rūz-1 pür-nūr eger şeb-i deycūrdur. 'Ale't-tevāli ve't-tetāyi ziyāret-i ravża-i cennet-i behcet ü müşāhede-i leme āt-1 envār-1 ḥażret-i risālet idüp her anda gūne gūne zevevk-i rūḥāni vü şarḳ-1 cāvidānī vü sa'ādet-i dü-cihānı taḥịilinde olup evā'il-i iḳāmetde ve ibtidā-yı evān-1 ziyāretde südde-i felek-rif' at-1 hażret-i risāletden ve āsitāne-i 'arş-menzilet-i ḩānedān-1 nübüvvetden șalla'llāhu 'aleyh ba de'l-istiḩāre ve'l-istişāre hüukm-i cihān-mețā' -1 vāfir vācibü'l-ittibā' a ḳarīb işāret-i perişs̄an ile bir nāyşekkervār on bir yirden bend-i kemer-bend ile ārāste vü bu nahll-i hidāyet-şümār āșār her bendi on beş nihāl-i dil-pesend ile pīāste ḳaṣideyi çün 'āṣilere ḳalem-i zebān-1 derbān-1 ḳalemden levḥ-i beyān u șahịfe-i tibyāna nāzil oldı:

\section{fe`ilātün mefā'ilün fe`ilün}

Ey Resūl-i Hudā-yı celle celāl

Vey benì müheyminü müte` àl

Evāsiț-1 mücāveretde ve eșnā'-i muḳārenet ü muvānesetde mihmān-1 ḥarem-i muḥterem ü mu' tekif-i mescid-i mu'aẓz̧am olmag̉la mecāz oldug̉umuz şeb çün ḳadr u leyle-i zāäü'l-bedrüñ rūz-1 pirūzında vü dem-i teneffüs-i șabāh-1 'ālem-sūzında bu terkịib-bend-i dil-pesendüñ evvel bendi vü zeylinden ba'żı ebyāt çün şehd ü ḳandı dahi āb-1 ḥayātvār cūybār-1 hāāme-i miskīn ' imāmeden beyāż nāme-i nūrāni cāmeye cereyān-1 vișāl eyledi:

\section{mef ūlü fầilātü mefā́ìü fă'ilün}

Küy-1 ḥabībe bu gice mihmān olam gibi

Hicr āhirir oldı vāṣıl-1 cānān olam gibi

ba' de ḳāfile-i ehl-i Medīne-i Nebī ile șalla'llāhu 'aleyhi ve-sellem rihlet ü rāhịile-i tạa 'ife-i ḥarem-i Ḥażret-i Muḥammed-i 'Arabì ile șalla'llāhu 'aleyhi ve-sellem müsāferet idüp def' a-i sāaniyede Allāhu Te'ālā celle ve 'alānuñ 'ināyetiyle ve yārān-ı bā-ṣafānuñ șafâ-yı himmetiyle naẓm: (22a)

\section{fe'ilātün fe'ilātün fe’ilün}

1. Sālik-i rāh-1 hakịịat oldum

Ṭālib-i mülk-i țariḳat oldum

\footnotetext{
46 “Muhakkak ki Peygamberi (s.a.v) ziyaret, (Allah’a yaklaştıran) en büyük amel, en çok istenen taat ve ün güzel ibadetlerdendir."

47 "En üstün müstehaplardan ve mendublardan, hatta vacib derecesine yakındır."

48 "Kim vefatımdan sonra beni ziyaret ederse hayatımda iken ziyaret etmiş gibi olur.” Hadis-i Şerif (Beyhakî).

49 "Kabrimi ziyaret edene şefaatim vacip oldu.” Hadis-i Şerif (Beyhakî).
} 
2. Cān u dilden idüben ḳaṣd-1 niyāz

Eyledüm 'azm-i reh-i mülk-i Ḥicāz

3. Haddine geldüm irüp miḳātuñ

Nice ḥad ḳapusına cennātuñ

4. ' Umre iḥrām-1 șafādur diyü cān

'Azm-i ḥacc eyledi lebbeyk-künān

5. Öpeyin diyü yeminu'llāhı

Șoyunup dökdi şi ār-1 rāhı

6. Şükr kim oldı urup rāha ḳadem

Ḥarem-i hāṣs-1 Hudāya maḥrem

7. İdüp iblīs hevā ile mużāf

$\mathrm{Sa}^{c} \mathrm{y}$ ile itdi gelüp beyti țavāf

8. Maraż-1 cān u dile virmege em

Eyledi nūş şarāb-1 Zemzem

9. Eyleyüp Mervede sa'y ile du' $\bar{a}$

Hâș̣l itdi yine 'ömrine șafā

10. Şükr kim oldı olup pāk-reviş

'Ākifān-1 ḥarem-i Ḥaḳka biliş

11. 'Āḳibet oldı maḳāmı 'Arafe

Fetḥ olup lāzıme-i men ' aref

12. Anda şevḳ ile münācāt ḳılup

'Arż-1 envā' -1 murādāt ḳılup

13. Ehl-i İslāmuñ idüp mi 'rācın

Giydi başına sa ādet tācın

14. Feyż ola tā ki aña raḥmet-i Ḥaḳ

Ol gice Müzdelife oldı yatak

15. İrgürüp irtesi gün meş ${ }^{`}$ ara rāh

Eyledi vāḳıf olup zikru'llāh

16. Anda taḥșil ḳılup makṣūdı

Anda tekmīl kılup maksūudı

17. Eyleyüp dīvle rezm ü bī-kār

Eyledi ' azm-i Minā remy-i ḥicār

18. $\mathrm{Ba}^{`}$ de beyt-i Hudāya irdi

Me'men-i ḳurb u riżāya irdi

19. Kendüyi luṭfa muḳārin itdi

Müfrid iken mütemetti` gitdi

(22b) ya'ni țavāf-1 Beytu'llāhu'l-ḥarām ve ziyāret-i ḥarem-i pür-iḥtirām u edā-yı erkān-1 menāsik-i ḥaccu'l-İslām ile 'umre șafā virilmek müyesser oldı. Elḥamdu-li'llāhi Te' ālā cemì si himmet-i aṣhāâ-1 șafā ile ve șafā-yı nazar-1 erbāb-1 vefâ ile eyser hạalāt üzre müncerr oldı. Ba' de edā'-i erkāni'l-ḥacc u itmām-1 ādābu'l-ḥacc u ve'ṣ-secc şehr-i żi'l-ḥiccenüñ yigirmi altısına dek 
yine kemākān-1 ḥarem-i mülk-i Mennān u ḥarīm-i beyt-i mālik-i deyyān-1 züül-imtinānda gāh 'umre vü șafā vü gāh niyāz-1 Bārī vü gāh me'men-i riżāda du'āda gāh tesbịh ü taḥmìd ü gāh tehlīi ü temcídde gāh niyāz-1 Bārî vü gāh girye vü zāride cemāhîir-i İslām u müşāhīr-i enām ile kimi ag̉lar kimi iñler kimi feryād eyler tābiş-i şevḳ ile suzān u lehb-i üns-i zevk ile fürūzān olmaḳ üzre idük. Şehr-i mezbūruñ sābi` -i 'işrininde yevmü'l-isnneynindeki mevlid-i seyyidü'lmürselindür. Nazm:

\section{fe`ilātün mefā‘ilün fe`ilün}

I

1. Hasretā hasretā ki derd-i dühūr

Ādemíde ḳomaz șafā vü sürūr

2. Fürḳatā fürḳatā ki gerdiş-i çarh

Getürür ādeme belā vü fütūr

3. Mị̣netā miḥnetā ki hịile ile

Merdi mag̀rūr ider bu dār-1 gurūr

4. El-fig̀ān el-fiḡān ki țālic -i bed

Komaz insānda şevḳ ü zevḳ ü ḥużūr

5. Hey dirìgā ki hak-i rāh-1 firāḳ

Dìde-i cānı eyledi bì-nūr

6. Hāy derdā ki meyl-i nefs-i denī

Beni luṭf-1 Hudādan eyledi dūr

7. Ya'ni Mecnūn mübtelā iken

Sinn-i Leylādan eyledi mehcūr

8. El-vedāc ey harīim-i beyt-i Hudā

El-firāḳ ey mețāf-1 rūḥ-efzā

(23a) II

1. Sāye-i beyt-i Ḥaḳda hoş-dem iken

Ehl-i Firdevs gibi hurrem iken

2. Șūretā bāb-1 Ḥaḳda bende olup

Ma nide pādişāh-1 bì-ğam iken

3. Bir av og̀lanı gibi bì-pervā

Ḥarem-i hāṣs-1 Ḥaḳka maḥrem iken

4. Yüzümüñ ḳarasıyçün ag̉lamada

Hacerü'l-esved ile hem-dem iken

5. $\mathrm{Ni}^{`}$ metüm raḥmet ü yirüm cennet

Şerbetüm Kevşer a' nì Zemzem iken

6. Eyü diyü hevā çıḳardı beni

Bāg̀-1 Firdevs içinden ādem iken

7. El-vedāc ey harīim-i beyt-i Hudāy

El-firāḳ ey metâf-1 rūḥ-efzāy 
III

1. Gerçi senden ḳażā ile gitdüm

Emr-i Haḳka rıżā ile gitdüm

2. Șanma kim bunda ihtiyārum ola

Belki yüz biñ belā ile gitdüm

3. Gitmedin geldi cevr-i devr-i felek

Nice nice cefā ile gitdüm

4. Āyinem șāf olup cemālüñden

Hamdu-li'llāh șafā ile gitdüm

5. İ́rişürsem peyāmuñ irgüreyin

Şevḳ-i nūr-1 Hुudā ile gitdüm

6. Ya'ni Taybe ili ziyāretine

Fikret-i Mușțafā ile gitdüm

7. Gelürin Haḳ șalarsa yine saña

Şimdi ben ol hevā ile gitdüm

8. El-vedāc ey harīim-i beyt-i Hudāy

El-firāḳ ey mețāf-1 rūh-efzāy

(23b) IV

1. Hey dirīgā ki miḥnete düşdüm

Vașl işi oldı fürḳate düşdüm

2. Kanı 'umre șafā vü cāna huzūūr

Cümlesi gitdi hasrete düşdüm

3. Raḥmete garḳ idüm belā-yı fỉāḳ

Cāna dāg urdı zaḥmete düşdüm

4. Menzilüm sāḥil-i necāt iken

Yine deryā-yı hayrete düşdüm

5. Baş açuk şāh idüm işigüñde

Bilmezem n'oldı nikbete düşdüm

6. Āsitānuñda devletüm var iken

Zellet irişdi żillete düşdüm

7. Vațan olmış iken baña eşigüñ

Felek ayırdı gurbete düşdüm

8. El-vedāc ey harīm-i beyt-i Hudāy

El-firāk ey mețāf-1 rūh-efzāy

V

1. Ey Hudā ḩānesi c ināyet ḳıl

Āhiretde baña şefā' at ḳ1

2. Seni ḳıble idenleri külli

Ṭamuya girmeden hịimāyet ḳıl 
3. Mü'minem lā ilāhe illa'llāh

Kāài olduḳda Ḥaḳ şehādet ḳıl

4. Hem Muhammed Resūl-i șādıḳdur

Hażretine sözüm rivāyet ḳ1

5. Seni varup ziyāret itdigümi

Fi` lümi ḳavlümi hịāyet ḳ1

6. Ey naẓargāh-1 Ḥaḳ be-ḥaḳḳ-1 Hudā

Fevrīnüñ ḳavline icābet ḳ1l

7. Gider oldı ḳapuñdan āh iderek

Sırr-1 Ḥaḳsın aña hidāyet ḳıl

8. El-vedāc ey harāim-i beyt-i Hudāy

El-firāk ey mețāf-ı rūḥ-efzāy

(24a) diyüp rūy-1 niyāzı ḥażret-i bì-niyāza țutup

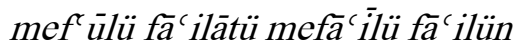

Yā Rab be-ḥaḳk-1 Ka' be ki seng-i bütān-1 ḥırṣ

Der-zemzem-i ‘ adem figen ez-ḳıblegāh-1 mā

diyü münācāt u 'arż-1 ḥācāt iderek āheste āheste dil-i şikeste vü cism-i nā-tüvān ü cān-1 haste ile girye vü zārì-künān 'alā-ḳadri’țttāḳat ü hasbe'l-imkān ber-vefkẹ-i emr-i șallū 'aleyhi ve sellimū teslimmăos şümār-1 aḳtār-1 emtārdan firāvān revāyiḥ-i șal"āt-1 şāi iḳa ile geh şemme-i şemām-1 nükheti lahlaha-i meşām-1 ḳudsiyān-1 melā’ik ü mādde-i ervāḥ-1 sükkān-1 seb`a erā'ik olmak elyak ü bir tabak meb'ādān Allāhü ve melā 'iketehū yüsallūne 'ale'n-nebiyy $y^{5 l}$ ta' dād-1 emvāc-1

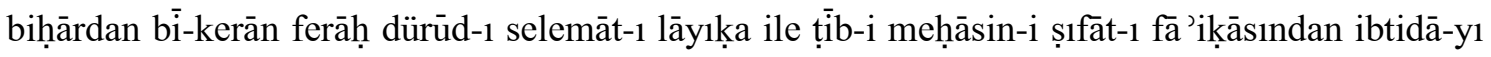
șaḥn-1 sāḥat-1 'ālem-i nāsūtdan tā intihā-yı mümteni ü'l-mesāḥa melekūt mu'aț̣ar olmaḳ muḥaḳkaḳdur. Gül-geşt-i ravża-i rażiyye vü ziyāret-i ḥaẓire sened-i evliyā vü seyyid-i enbiyā naẓm:

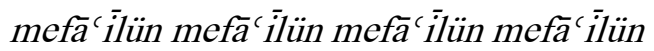

1. Muhammed kim ene efșa $h^{52}$ cemālinden bir āyetdür Ene efșạ̣ maḳāli ḥāl ü kālinden rivāyetdür

2. Muhammed kim beyāż-1 'ārıż u gìsū-yı miskīini Șabāh-1 ‘ id ü leyl-i ḳadr ikisinden hikāyetdür

3. Muhammed kim riyāż-1 ravżasıyla ḩayl-i huuddāmı Biri Firdevs-i a' lādur biri ġılmān-1 cennetdür

4. Muhammed kim livā-yı ḥamd anuñ nāmına açıldı Hudādan șoñra Mạ̣mūd ol durur nāmı işāretdür

5. Muhammed kim şeh-i dünyā vü ' uḳbā didügüñ Fevrí Anuñ manzūurı ' abd-i kemterīninden ' ibāretdür

eylemek niyyetiyle 'āzim-i cānib-i Yeșrib olup merāḥil ü menāzilde vü meşāric ü menāhilde vāḳic olan ețvār ü ās̄ār-1 zevi'l-i' tibārı temāşā vü seyrān ü teferrüc ü iž ān idüp ve gazve-i Bedr

\footnotetext{
50 "Siz de ona salât edin, selâm edin.” Ahzab Suresi 56. ayet.

51 "Şüphesiz Allah ve melekleri Peygamber'e salat ediyorlar." Ahzab Suresi 56. ayet.

52 "Ben en açık ve düzgün konuşanım.” Hadis-i Şerîf.
} 
ü Ḥuneynde düşen șaḥābe-i güzīn ü ḳurb-1 Vādì-i Ġazālda āsūde olan şühedā-i erba ỉni ziyāret iderek sene 953 Muharremü'l-ḥarāmınuñ yedinci güninde (24b) dem-i șabāḥda ve āḩir-i revāḥda beled-i mușābiḥ-i șabāḥat ü Medīne șabāḥ lețāfetüñ sūr-1 sürūrından:

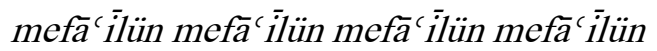

1. Ne hoşdur kişinüñ yā Rab mekānı kūy-1 yār olmaḳ Huusūṣā yār-1 maṭlūbı habīb-i Kirdigār olmaḳ

2. Ne hoşdur maḥrem-i kūy-1 ḥabīb olmaḳ kişi añsuz Husususạā kim ḥabỉbi maḥrem-i perverdigār olmak

3. Ne ḩoşdur menzil-i maḳșūda ermek nāgehān ādem Huușūṣā menzili şehr-i şeh-i dār u diyār olmaḳ

4. Ne ḩoşdur ḳapusında ḳulı olmaḳ şāhınuñ bende Husụusạā şāhı serdār-1 diyār-1 bī-şümār olmak

5. Bi-ḥamdi'llāh müyesser oldı ol sulțān kūyınuñ Ayaġı altına huddāmınuñ Fevrí gubār olmaḳ

diyüp dāhil ü bir maḳām-1 dil-güşā vü feraḥ-bahşāada nāzil olup ziyāret-i Hażret-i seyyidü’lenām ü țavāf-1 ravża-i münevvere-i imām-1 kirām 'aleyhi'ṣ-șal'ātü ve's-selām ile müşerref ü muggtenem olup ve üç güne dek ol ḥarem ve ol āsitan-1 mu'aẓzamda gāh secde-i şükr-i perverdigārla çihre vü cebīni ālūde-i ḩāk ü gāh tevbe ve istiğfārla mir'āt-i ḳalbi jeng-i günehden pāk ü gāh esrār-1 müşāhede-i ravża-i cennet behişt ile cānı ḩandān ü feraḥnāk ü gāh iḳtibās-1 envār-1 merḳad-i münevver-i Ḥażret-i Risālet ile şem 'i dili tābān ü tābnāk idüp cemíc ahyyān u ahyāzda 'uḳbet-nümāz u eșnā'-i niyāzda yārān-1 süḩan-sāz u terāne-perdāzı daḩi du'ā kendü nefesiyle enbāz idüp ḳıț a:

\section{fe'ilātün mefā'ilün fe'ilün}

1. Ey fașị̂-i ' Arab belìg-i Ḳureyş Medhiüñe çalışur bu ebkem ü lāl

2. Bāg̀-1 vașfuñda belki bülbülveş $\mathrm{Na}^{\prime}$ tuñ ezber ḳ̂lur hep ạ̣fel-maḳāl

3. Belki pīr ü cevān-1 zümre-i dīn Medhüñ oḳur hemişe māh ile sāl

4. Hạk kerīm ü senüñ dahi luțuñ Baḥr-1 raḥmet mis̄āli māl-ā-māl

5. Kụl şefā́ at ḳamumuza luṭf it Dimezem kim kemini gör birin al

(25a) diyüp nāle-i cān-güdāz ü feryād u figgān-1 pür-sūz u sāz üzre idük. Şehr-i mezbūruñ onıncı güni ki yevmü'l-ișneyn idi. Menzil-i zā'ir-i felek-i çārümīn evc-i ḳubbe-i hażrā vü maḥfel-i ḥațîb-i nūrāni cāmic -i semāvāt $u$ arżin minber-i mescid-i Akṣā-yı felek a lā olmışdı. Ve hurūşāan-1 cāmic -i mecāmic -i 'arşuñ feryād u fig̉ānı aḳāṣi arż u semāya ve mü'ežżinān-1 cevāmic -i șavāmic -i ferşüñ șalā vü ezāanı ḳașārā-yı deyr-i dünyāya intihā bulmış idi. Ve ḳầ ide-i ma' rūfa 'ādiye vü țariḳa-i me 'lūfa yevmiyeleri üzre ol țavāf ve ziyāretin temām ü ber-du'à vü ḥuṭbesi ' ibāretin itmām idüp biri diyār-1 Zengibāra rāḥil ü biri hażī̇̇-i Mag̉rib-zemīn-i teng ü tāra nāzil olmag̉a başlamışlardı. Ve sulțān-1 Hāver diyār-1 şarḳdan hacca ḳaṣd itmiş zā irdār gelüp ziyāret-i Ḥażret-i Muḥammed Muștafā vü țavāf-1 ḳubbe-i Ḩażrā ile iktisāb-1 envār idüp 
siyāh-fām ẓalām-1 maḳām-1 Beytü'l-Ḥarāma niyyet ü pādişāh-1 felek çārümīn cāme-i siyāh olan Beytu'llāhuñ bāb-1 şerífinden çı̣̂u ziyāret-i sālār-1 Yeșrib ü mālik ü serdār-1 ārāżīi maşrık u mag̉ribe 'azm itmiş hāài-kirdār ziyāret-i Ḥażret-i Nebì țavāf-1 Ravża-i Muḥammed-i 'Arabí ile șalla'llāhu 'aleyhi ve-sellem pür-nūr u tābdār olup cānib-i Şāma 'azīmet eylemişdi ya'nī ki naẓm:

\section{fă ilātün mefā'ilün fe'ilün}

1. Vaḳti ẓuhruñ kemāle irmişdi

Mihr-i enver zevāle irmişdi

2. İdüp ol meh diyārını seyrān

Ġarba 'azm itmiş idi mihr-i cihān

3. Virmek ile teb-i firāk aña derd

Ditreyüp olmış idi çihresi zerd

Bu mihr-i felekden dūr ol āsitāne-i sa ādetlü mehcūr zavallu dahi du`ā vü senā dehānın açup ve zebānından nār-1 ḥasretler șaçup hezārān sūz u güdāz ü ālāf-1 tażarru' u niyāz ile ol türāb-1 südde-i (25b) 'izzet iktisāba ki iksīr-i sa ādet-i dü-cihāni vü kīmyā-yı siyādet-i cāvidānīdür. Bu rūy-1 zerd ü zārı sürüp ve ol gubār-1 müşār ḥarīm-i maḥrem-i muḥteremi ki kuḥl-1 cilā-yı dìde-i a c yān-1 vücūd u tūtiyā-yı remed-zā-y1 ' uyūn-1 aṣhāāb-1 şühūddur. Bu dỉde-i pür-derd-i eşkbāruñ cārūb-1 müjgānıyla süpürüp birin zer-i ḩāliṣ-i temāmü'l-' 'yār gibi gill ü gişsdan pāk ü birin çeşme-i āfitāb-1 pür-envār gibi gaym-i ġş̧ādeden halāṣ u rūşen ü tābnāk

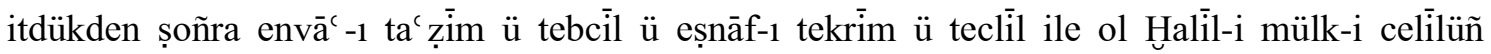
cenāb-1 cemil ü 'utbe-i ' arş-1 ' adīlin şifāh-1 meskenet ü tezellül ile taḳbīl idüp:

\section{făcilātün făcilātün făcilātün făcilün}

1. El-vedāc ey āsitān-1 server-i dünyā vü dīn

El-firāḳ ey ḥāk-i pāk-i șaḥn-1 Firdevs-i berīn

2. El-vedāc ey ḳıblegāh-1 sākinān-1 āsumān

El-firāḳ ey secdegāh-1 zümre-i rūy-1 zemīn

3. El-vedāc ey ravża-i Rıżvān gülistān-1 İrem

El-firāḳ ey sāḥat-1 gülzār-1 iḳlīm-i yaḳin

4. El-vedāc ey 'arṣa-i sulțān-1 iḳlìm-i hüdā

El-firāḳ ey cilvegāh-1 raḥmeten li'l- ālemīn

5. El-vedāc ey bāb-1 raḥmet vey der-i dārü's-selām

El-firāk ey cāy u hạay u mehbiṭ-i Rūhu'l-emīn

6. El-vedā` ey şāh-rāh-1 şāh-1 şāhān-1 sübül

El-firāḳ ey türbetü iḳdām-1 fahrü'l-mürselīn

7. El-vedāe ey ma`́ den-i maḳșùd kān-1 kün-fekān

El-firāḳ ey menba` -1 baḥr-1 hüdā-yı mühtedīn

8. El-vedāc ey maḥzen-i mațlūb-1 künc-i küntü kenz

El-firāḳ ey ḳulzum-i dürr-i yetim 'aḳl u dīn

9. Yā Resūla'llāh ne haddümdür saña itmek vedāc

Āb u hāaüm hem-zebānum hoşdur olmaḳ mā ü țin

10. Bir yüzi ḳara günāh-ālūde mücrim bendeñem

Eş-şefā'a yā Resūla'llāh ü Rabbi'l-‘ālemin 


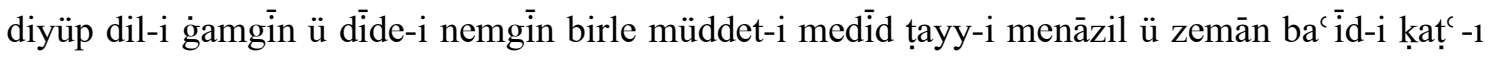
merāḥil idüp āḩir vüșūl-1 dārü’s-selām a'ni duhūl-i memālik-i Şām u mușāḥabet ü mukāarinet 'ulemā-i 'izaām (26a) ve fużalā-yı kirām ü ziyāret-i müşāhid-i cemāhīir meşāhīir-i ehl-i İslām ile

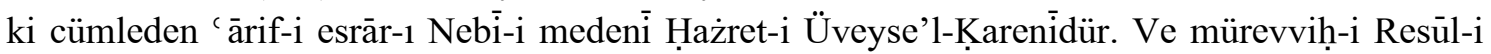

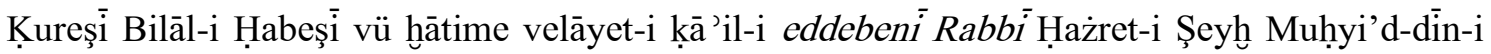
'Arabī ve bunlardan gayrı nice nice evliyā-i dīn ü enbiyā-i güzīn ü aṣhāb u etbā' -1 seyyidi'lmürselīndür rıżvanu'llāhi te ālā 'aleyhim ecma' inn. Ve ba' de țavāf-1 mesākin-i pīr-i Ken ān 'azm ü i'tikāf-1 künc-i beytü'l-aḥzān ve esrā-yı Mescid-i Akṣā ve temāşā-yı șaḥratu'llāhu'ṣșammā. Seyrān-1 ețrāf-1 Beytü'l-Maḳdis ü devrān-1 eknāf-1 cevānib-i arż-1 aḳdes ziyāret-i cenāb1 Hualīlü'r-Raḥmān ve rü 'yet-i āsitān-1 Kelīm-i İbn-i 'İmrān 'aleyhima'ṣ-ṣalavātü ve's-selām ve

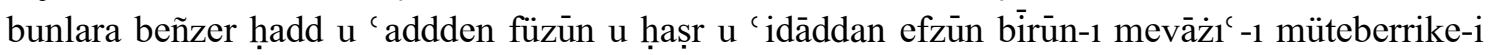
enbiyāya vușūl ü mecāmi -i müteferriḳa-i evliyāya duhūl ile müşerref olup hāàiyā ḩıdmet-i şerīf şeref-fezā-yı yārān ile ve hāk-i pāy-1 kỉmyā-sāy-1 ḩullān ile dil-i gamgīni mesrūr u dỉde-i gamgīni pür-nūr ḳılmaḳ ārzūsiyla vilāyet-i Rūm u merzübūm-1 sa'ādet-i mersūm semtine 'azìmet üzreyüz. Hudā 'alīm ü dānādur ki tā ibtidā-yı müşāhede-i nūr-1 sāṭ̂' '1 Beytu'llāh u iftitāḥ-1 me āniye-i mihr-i lāmi -i habīb-i İlāhdan nihāyet ādāb-1 ziyāret ü erkān-1 hạcc u gāyet-i ạ̣kām-1 țavāf u menāsık-1 ḥacc u șecce dek belki evvel 'azm-i sefer-i ẓafer-i rehber ü āgāa-1 ḥazm u cezm-i seyr ü güzer-i baḥr u berden tā āhnir müsāferet ü mücāveret-i Yeșrib ü Batḥā vü müntehā-y1 mu'ārinet ü mübā' det maḳāmāt-1 sübḥāne'llezí esrā bi-'abdihí leylan mine'lmescidi'l-ḥarāmi ile'l-mescidi'l-Akṣă ${ }^{-53}$ belki mücāvize hudūd-1 Ḥumș u Ḥamāya dek ki anlar dahi aṣhāa u tābi î̀ ile țolu ve enbiyā-i mürselīn ile memlūdur. Gāh mežkūr olan mecāmic $-i$ șavāmic -i 'āliye-i enbiyā-1 müteḳaddimīn ü gāh mesțūr (26b) olan șavāmic -i cevāmic -i müte ālìye-i evliyā vü şühedā-i müteahhirinde ve haremeyn-i mükerremeyn ü beldeyn-i mu' az̧zameteynde gāh cenāb-1 bāb-1 Beytu'llāh u harīm-i ḥarem-i 'arş-1 iştibāhdan her rükn ü maḳāmda taḥt-1 mīāà u mültezem ü rükn-i ehl-i şāhide vü gāh Ravża-i Münevvere sulțān-1 kā 'ināt ve ḥużūr-1 merḳad-i muṭahhar mefhar-i mevcūdātda ve bunlardan mā' adā bilād-1 ḳarada eger mesācid-i Nebevi ve mu`āabed-i Muștafavīdür. Eger müşāhid-i șahābe-i kirām ü merāḳid-i āl ü evlād-1 'iẓāmdur. Eger mahāfill-i mevāli vü ahālì dār u diyār u menāzil-i ekārim ü e āli ḳarīn ü emșārdur. Eger mecma' -1 șulehāa vü etḳiyā vü müctemi'-i fuḳarā vü gurebādur. Ve bi'l-

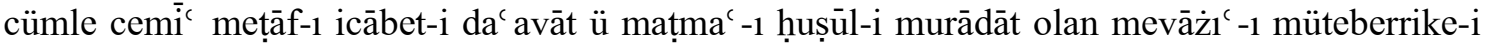
şerife ve șavāmi' -i müteferriḳa-i münífede siyemmā zamān-1 vaḳfe vü münācāt u āvān-1 'arż-1 ḥācāt u hengām-1 ḥuṣūl-i murādātda zirve-i kühsār-1 raḥmet ü kulle-i mehbiț-i bereket dāğ-1 dil-i 'āşık menāl-i pertev-i envār-1 İlāhi ile tābān u leme āt-1 esrār-1 nā-mütenāhì ile dırahşān olan cebel-i 'Arafāt ve eşref-i şevāhik-i 'āliyān ețrāfında olan feżā-yı bì-pāyān u eknāfında olan feyfā-yı bì-girānı ki 'arż-1 garaż 'arż-şiken ehl-i dünyādan 'arì̇ ü țūl-i emel-i muṭavvel țâlib-i

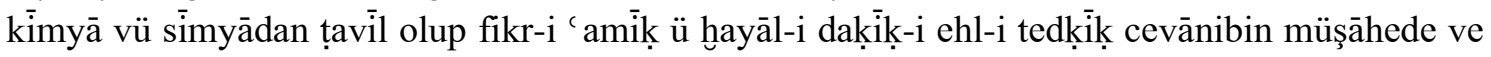
taḥkịk eylemekden bīrūn u ḥāl-i haşyet-i memālik dīde-i remed-dīde-i gufle-i enāma vü aḥvāl-i ma' rifete hakạāyıḳ-1 hey'etüñ ḳuvvet-i 'āḳile-i cehle-i ' avāma bu' dından efzūndur. Gūyā cānib-i ibtidāsı mesālik-i ‘ avālim-i ḳademe muttașıl u muḳterin ü cevānib-i intihāsı memālik-i mu ālimi 'ademe müntehì vü mefrūndur beyt:

fe'ūlün fe'ùlün fe'ülün fe' ùl

Ne țūlına irmek müyesser țariḳ.

$\mathrm{Ne}$ 'arżına irmek ḩayāl-i daḳiḳ

\footnotetext{
53 “Kulunu (Muhammed’i) bir gece Mescid-i Haram’dan Mescid-i Aksa'ya götüren Allah'ın şanı yücedir.” İsra Suresi, 1. ayet.
} 
baḥr-1 bì-ḳa' $r$ u (27a) bün ü gird-āb-1 mühliketü’s-süfün gibi 'adād-1 merātib-i a' dādan füzūn ḳulzüm-i ervāḥ-1 kümmel-i insān ü vāfirā vü șalāḥ u sedād u āḥād u żalāl ü fesād ḳurā vü bilāddan efzūn deryā-yı eşbāh ehl-i ‘ irfân ile bir vech ile memlū vü māl-ā-māl ü bir țariḳle lebā-leb ü peymāne-mișāl iken ki tezāḥum-1 terākim-i emvāc-1 bihār tebār-1 nisā vü ricālden ve teșādum-1 telâțum-1 efvāḥ-1 süyūl-i huyūul ehl-i cimāl ü big̣āldan ve terādüf-i teșādüf-i āhāli nümür-i humur gazāl-tims̄ālden ve teḳāsüf-i teżāe uf-i cūy-bār-1 piyāde vü süvār-1 pür-vecd ü ḥālden keştīi zemīn yirinden kopup deryā-yı felege irüp baḳayazmış. Ve fülk-i felek-berīn mekānından șalınup māverā-yı ' arşda ḳaraya atayazmış idi. Ve her țarafdan selāṭinn-i zamān u

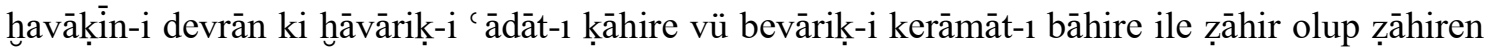
dervişsșūret ser-i pā-bürehne vü 'uryān u ma'nīde pādişāh-sīret hil' at-i kerāmet ile mülebbes muḳtedā-yı zemīn ü zamān ki geh muḳātele vü mücādele-i ceyş-i nefs ü hevāya gelmiş ve fetḥ ü fütūḥ-1 ḳal' a-i raḥmet-i Hुudāya niyyet ü ‘ azimet eylemiş ` aziżlerdür. Naẓm:

\section{fe'ilātün mefā'ilün fe'ilün}

1. Harkẹ ' ādātdan idüp hırḳa

Terk-i dünyādan eylemişler tāc

2. Tācdāra yoḳ iḥtiyācları

Tah̆t u tāc ehli anlara muhtāc

Dūd-1 āh-1 pür-şerārlarından siyāh bayraḳlu altun sancaḳları vü mug̉ber perçemlü tūğ-1 pür-fürūğları sūr-1 āsumānda açılmış ve seyl-āb-1 eşk ü hūn-āb-1 sirişkden ' asker ẓafer rehberleri cūşān u hurūşān olup rūy-1 zemine țag̉ılmış idi vü sỉne-i bì-kỉnelerinden żarb-1 müşt ü mıżrab-1 engüșt ile țabl ü neḳkāreleri (27b) giryān u nālān u feryād u zār u nāle-i bisyārlarından șūrnā vü nefïrleri pür-fig̀ān ü na'ra-zenān olup sāyir huccāc-1 pür-cūş-1 bezm-i elest mestleriyle vü nāciyān u pür-hurūş hum-hāne-i 'aşkẹ-1 bāde-perestleriyle hem-āvāz olup cān u göñülden ve derūn-1 dilden ag̉ız bir ve nāle-i cihāngīr idüp ve 'aşk ile Allāh Allāh eyleyüp șadā-yı lebbeyk ü nidā-yı sa' dīk ile ḳubbe-i 'arş-1 berīne vü ețrāf u eknāf-1 āsmān u zemine bir mertebe velvele-i

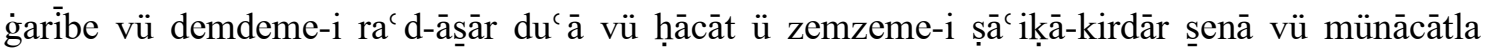
revāyā-yı deyr-i dünyāya vü ḳașāāā-yı arż u semāya bir dā'ire zelzele-i ' acíbe vü kevkebe-i șavt-1 tehlīl ü temcīd ü debdebe-i kūs-1 tesbịh ü taḥmīdle kūs-1 sevākin-i felek-i ac lāya vü hevesi Sübḥān-1 Sidretü'l-Müntehāya bir veche gulġule-i mehībe șalmışlar idi ki cāmi`-i Ezher-i semā vü mescid-i enver-i Akṣā vü șavma`a-i çarh-1 berin ü hānkāāh-1 rūy-1 zeminde hațîb minber ü seccādesin maḥfel-i ferş-i imām Ka'be-i ḳuds ü hümām Medine-i üns-i huṭ̣be vü żikrin ve ḳıāàat u fikrin yañılmış ve öñlerin hayret alup 'aḳılları țag̉ılmış idi. Ve hikmet-i İlāhī ve ' ināyet-i nā-mütenāhí ile ol dem ki vaḳfede olan ehl-i hạātuñ rabbenā teḳabbe'l-minnā inneke ente's-semi' 'ü'l- 'alìm ${ }^{54}$ nidāsı basiṭ-i hāakden zirve-i eflāke peyvest ü aṣhāb-1 münācātuñ vetüb 'aleynā inneke ente't-tevvābü' r-rāhịim ${ }^{55}$ șadāsı hażiż-i ferşden geçüp müsebbihāan-1 evc-i ' arşuñ taḥmīd ü temcídi anuñ yanında pest olmışdı. Bir cānibden sehāb-1 cevv-i āsumān (28a) ve hüve'llezí yünezzilü'l-ġayșe min ba'di mā-kanetū ve yenşuru raḥmeteh ${ }^{56}$ diyüp gürūh-1 ehl-i imān gibi giryān u eşk-i nīrān gūyā ki kelām-1 Ḥaḳdan tercemān olup anı ucíbü'd-da'vetü'd-dā' $i$ izaā $d e^{`} \bar{a} n I^{37}$ kelāmiyla raṭbu'l-lisān ü bir cānibden rac d-1 șā' iḳa-girdār-1 felek-i devvār

\footnotetext{
54 “Ey Rabbimiz, bizden kabul buyur! Şüphesiz sen hakkıyla işitensin hakkıyla bilensin.” Bakara Suresi, 127. ayet. 55 “Tövbemizi kabul et. Çünkü sen, tövbeleri çok kabul edensin, çok merhametli olansın.” Bakara Suresi, 128. ayet.

56 “O, insanlar umutlarını kestikten sonra yağmuru indiren, rahmetini her tarafa yayandır." Şûrâ Suresi, 28. ayet.

57 “(Kim) bana dua ederse, dua edenin duasını kabul ederim.” Bakara Suresi, 186. ayet.
} 


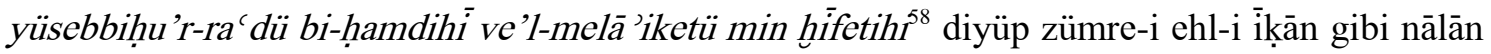
ü na' ra-zenān u 'inābet-i Mennān-1 züu'l-imtinānı '1yān idüp ve hüve'llezí yaḳbelü't-tevbete 'an

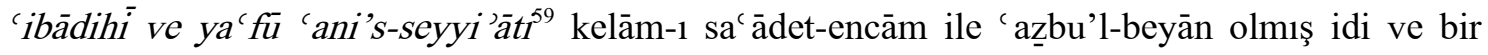
cānibden ehl-i ictimāe dan ba żi gözi açıḳlar ıțtılā' itdügi hayl-i melā'ike pür-vecd ü semā' ki ḳavm-i evveli ecniḥatün müsennā vü șelās ü rubāc idi. Huūn-āb-1 eşk-i ehl-i İslāmı ve seyl-āb-1 sirişk-i ḩavāṣ u 'avāmı āb-1 revān u seyl-i revān gibi göricek zebān-1 hāl ile ba' żısı lā-tehāfiu

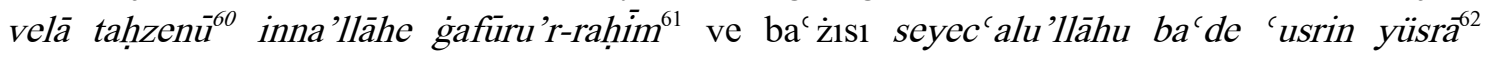
inna'llāhe hüve't-tevvābü'r-rahịm ${ }^{63}$ diyü mü 'minine beşāret-i dil-güşā vü işāret-i ferah-fezā idüp giymişlerdi. Ve bi'l-cümle bunuñ gibi nice nice 'alāyim ḳabūl-i hạāât u āsāâr-1 isticābete de' avāt zuhūr idüp leb ü dehān ehl-i ežkār ü çeşm-i giryān-1 uli'l-ebșār fe'l-yażhakū kalīlen ve'l-yebkū kesiran ${ }^{64}$ ma'nāsı āb-1 revān gibi tekrār eylemek üzre iken bir dem ve bir nefes hāmūş olmayup żimmetümüzde du' ā-yı hayrı lāzım olanları ferāmūş itmeyüp gāh olurdı ki 'umūman 'āmme-i mü'minin ü cümle-i muvaḥhidīin [ü] müslimīn içün naẓm:

\section{fe'ilātün mefā'ilün fe'ilün}

1. Zümre-i ehl-i dīne yā Rab

Mușțafā ḥürmetine raḥmet ḳ̂l

2. Dīn ü dünyāların ḳ̂lup ma` mūr

' Āḳıbet yirlerini cennet ḳıl

(28b) ve gāh olurdı ki hușūṣan pādişāh-1 mülk-i dīn ü ser-i sālār-1 ehl-i yaḳin Hażret-i Sulṭān Süleymān eyyeda'llāhü Te ālā bi-nașrihì ilā āhiri'z-zamān ${ }^{65}$ içün Allāhümme hebli mülken lāyenbagi li-ehadin [min] ba' dih ${ }^{66}$ nazm:

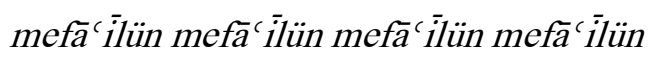

1. Huudāyā şeh Süleymānı yedi iḳlīme mālik ḳıl

Ḥabībüñ Mușṭafānuñ cādde-i şer inde sālik ḳıl

2. Cihān țurdukç̧a taḥt-1 ' izzet üzre kāmrān olsun

'Adū-yı dīn-i İslāmı yed-i ḳahrında hālik ḳı

ve gāh vüzerā-yı serīr-i salṭanat u ümerā-yı ețrāf-1 memleket içün

\section{fe'ilātün fe'ilātün fe'ilātün fe'ilün}

1. Vüzerā vü ümerāya kerem eyle yā Rab

Luṭf vir tā ki re` āyāya ri` āyet ideler

2. Fānímanșibda ' adāletle beḳā üzre olup

Dünyeden āhirete ehl-i sa' ādet gideler

ve gāh ‘ ulemā-yı dīn ü fużalā-yı ehl-i yakịin içün naẓm:

\footnotetext{
58 “Gök gürlemesi O’na hamd ederek tespih eder. Melekler de O’nun korkusundan tespih ederler.” Ra’d Suresi 13. ayet.

59 “O, kullarından tövbeyi kabul eden, kötülükleri bağışlayan ve yaptıklarınızı bilendir” Şûrâ Suresi, 25. ayet.

60 "Korkmayın ve üzülmeyin." Fussilet Suresi, 30. ayet.

61 "Muhakkak ki Allah çok bağışlayandır, çok merhamet edendir.” Bakara Suresi, 192. ayet.

62 “Allah, bir güçlükten sonra bir kolaylık yaratacaktır.” Talak Suresi, 7. ayet.

63 "Şüphesiz O, tövbeleri çok kabul edendir, çok bağışlayandır.” Bakara Suresi, 37. ayet.

64 “Artık az gülsünler ve çok ağlasınlar.” Tevbe Suresi, 82. ayet.

65 "Allahu Teala yardımıyla onu ahir zamana kadar destekler."

66 “(Ey Allahım), bana, benden sonra kimseye lâyık olmayacak bir mülk (hükümranlık) bahşet!” Sad Suresi, 35. ayet.
} 


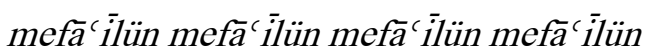

1. Mevālìye ḥabībüñ ḥaḳḳı'çün yā Rab 'ināyet ḳıl

Rumūz-1 'ilmüñi keşf eyle anlara hidāyet ḳıl

2. Cihānda fi` 1 ü ḳavlin cümlenüñ șer ${ }^{`}$ a muvāfiḳ it

Ḳyāmetde kitāb-1 hü̈nüñe baḳmagia lāyıḳ it

Dügāh ḳużāt-1 memālik-i İslām ü ḥumāt-1 mesālik-i ìtām-1 enām içün naẓm:

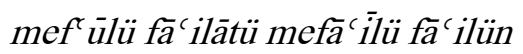

1. Hükmini ehl-i şer üñ İlāhì șahịị ḳ̂l

Ḥıf̣ eyle cümle anları māl-i yetimden

2. Dünyāda eyle her birinüñ rif́ atin ziyād

Șoñ demde șaḳla hevl-i ' azāāb-1 cahịmden

ve gāh meşāyih ü 'ubbād u fuḳarā vü zühhād içün naẓm:

fe'ilātün fe'ilātün fe'ilün

1. Sulehānuñ fuḳarānuñ yā Rab

Arturup faḳr u fenāsını müdām

2. Evvelā keşf ü kerāmāt virüp

Āhiri it yirlerini dār-1 selām

ve gāh zümre-i muhașṣ1lān-1 'ulūm-1 firḳa-i mükemmelān-1 rusūm a'nī ki tạalib-i mecd-i mülāzım u sūhte vü müste` id ḳardaşlar içün naẓm: (29a)

fe'ilātün mefā́ ilün fe'ilün

1. Zümre-i țālibīnüñ ey kāàdir

Eyle ' ilm ü 'amellerini ziyād

2. Cümlenüñ ḳ̂l ' aḳā ’idini șahịh

İrgürüp makșadına rūz-1 mi ${ }^{\complement} \bar{a} d$

ve gāh şu' arā vü ẓurefā vü bülegāa vü fașịhā yazanlar içün naẓm:

fe'ilātün fe'ilātün fe`ilātün fe`ilün

1. Şā̄ ire münşiye yā Rabb 'ināyet eyle

Ki ḳamu sözlerini na't ya tevḥid ideler

2. Bunda hezl ü hezeyāndan șaḳınup dillerini

Cennetüñ vir k'ebedi žātuña tạ̣mìd ideler

ve gāh aṣhāâ-1 şevḳ ü erbāb-1 ževk [ü] 'āşı̣ān-1 pāk ü muhibbān-1 gamnāk u hem-derdler içün

mef ùlü fă ilātü mefā' ìlü făcilün

1. Erbāb-1 'aşḳı ḳanțara-i pür-mecāzdan

Yā Rab geçür șafã ile irgür hakịikate

2. Dünyāda āb-1 'aşkuñ ile bula hayāàt

Āhir geçüp șırātı ḳamu gire cennete

ve gāh țā'ifeteyn-i āhireteyn ü ḳıbleteyn-i müte'ahhireteynden ta'yīn ü tahșiș̣ ve icmālen mezkūrken tanșịi idüp naẓm:

fe'ilātün fe'ilātün fe'ilātün fe'ilün

1. Bir ḳuluñ vardur İlāhì kim adı ' Āşıłkẹdur

Rāh-1 'aşkununda senüñ gāayet ile șādıḳdur 
2. Baña 1ṣmarladı ḳapuñda münācāt-1 ḳalem Anuñ içün țapuña keşf-i murādāt-1 ḳalem

3. Kāāirā hicr ile miḥnet-zede bir ' āşıḳdur Dürlü miḥnetle felāket-zede bir ' āşıḳdur

4. 'Aşḳdur vāye aña 'aşḳ durur ser-māye 'Aşșdur ' aşk ạteşidür tā geleli dünyāya

5. Fenn-i ' aşḳuñda bu gün māhir ü fāyık olmış 'Aşḳı bulmış sevecek 'aşḳa o 'āşı̣ [olmış]

6. Kendüye devlet-i cāvìd ile himmet ider Muștafā āline da'vā-yı ' ubūdiyyet ider

7. Zerreden gerçi cihān içre vücūdı kemdür Pertev-i mihrüñe ümmídi veli muhkemdür

8. Beşeriyyetdür egerçi günehi żilleti çok Kerem ü 'afvuña hiç şā’ ibe şübhesi yoḳ

9. Dimezem hü̈km idüp elbet kereme lāyıḳdur Raḥmet eyle aña yā Rabb hele 'āşı̣̂dur (29b)

10. Yầ İlāhi kerem ü luṭuña gàayet yoḳdur Baḥr-1 iḥsānuña miḳdār u nihāyet yoḳdur

11. Anı bir vech ile eyle keremüñ baḥrına garḳ Ki bata gide aña cümleten ez-pā tā fark

12. Nām1 'Āşıḳdur eyā raḥmeti çoḳ raḥmet umar Sevdigüñden dahi bu ḳıșșada çoḳ şefḳat umar

13. Dünyede ḳıl anı yā Rabb şeh-i ' ālem-i ' aşk Ser-te-ser aña musaḥhạar ḳıla bu ' ālemi 'aşk

14. Şāh ḳıl ‘ āşıḳu'l-` aşḳ ilinüñ sancag̉ın 'Arş-1 a' lāda ḳura 'aşḳuñ ile otaġin

15. Āhiretde an ' 'aşk ehline serdār eyle Server-i maḥşere yā Rabb 'alemdār eyle

16. 'Aş̧ sancaġını tā ol çeke ol günde revān Ser-i ' alem gib'ola āl idügi anda ' yyān

17. Diyeler 'Āşı k̦a virilmiş o sancaḳ Hạậan Fevríyi dahi İlāhi ḳopar ol sancaḳdan

18. Cümle aṣhāàba vü aḥbāba daḩi yā Rabbì Sen kerem eyle şefí ${ }^{`}$ ola beni 'Arabi

19. Ḥażret-i Aḥmed-i Muhtār ḥaḳiyçün yā Rab Reh-i 'aşkunundaki ahbār ḥaḳiyçün yā Rab

20. Yarlıganmaḳ var ise ḳavl-i du' āsıyla ḳul Ben yüzi ḳara ḳuluñ eyle du'āsın ḳabūl 
diyüp ve buña beñzer hezārān hezār ed iye-i devlet-i cāvidāni vü eșniye-i sa ādet-i dü-cihāni ile raṭbu'l-lisān ü 'ažbü'l-lisān olmaḳdan bir laḥza hāāli degül idük. Ve inşā’allāh şimdengirü dahi mādām ki 'ālem-i hayātda sākin ü dünyā-yı bì-șebātda mümkin olavuz ol zāât-1 melek-ṣ̂fât içün bunuñ emsāali ve 'adāt-1 șāliḥāt-1 șalavāt-1 ma' rūża-i evḳāt gibi üzerimüze lāzımu'l-edā vü vācibü'l-ḳażā olup ve yārān-1 șafā ve hullān-1 vefāya ta 'mīm dahi tașmīm olınmışdur müyesserbādā bāḳi ve's-selām ke'l-evveli bi'l-itmām ve'l-ekmel. Vaḳfe burda temām olsun bizi bilenlere peyām olsun șag olursaḳ buluşmadur makșūd biz ölürsek size selām olsun

\section{fācilātün făcilātün făcilātün făcilün}

Ṭā 'if-i beyt-i Hudā vü zā ir-i bāb-1 Resūl

Fevrī ya nì ḩāk-i rāh-1 āl ü aṣhāb-1 Resūl

\section{Sonuç}

Seyahat-nâmeler, klasik Türk edebiyatında dış dünyaya açılan ve sosyal çevreyi yansıtan edebî türlerden biridir. Manzum, mensur veya manzum-mensur şekillerde karşımıza çıkan bu tür, seyahatin yapıldığı coğrafyaya ve amaca göre kendi içinde sinıflandırılmaktadır. Hac ibadetini yapmak üzere çıkılan seyahatler esnasında yaşanan tecrübeleri ve gezip görülen yerler hakkında izlenimleri konu alan hac seyahat-nâmeleri de bunlardan biridir.

Klasik edebiyatta 15 . yüzyıldan başlayarak 19. yüzyıla kadar birçok hac seyahat-nâmesi kaleme alınmıştır. Bunlardan biri de 16. yüzyılın velut şairlerinden biri olan Fevrî tarafından manzum-mensur karışık şekilde telif edilen ve bu çalışmada da hakkında çeşitli değerlendirmelerin yapıldığı hac seyahat-nâmesidir.

Fevrî, bu eserinde 1544 yılında çıkmış olduğu hac yolculuğunu konu edinmiştir. Meşâ 'irü 'ş-Şuarâ'sında da dile getirdiği üzere Fevrî'nin hacca gideceğini öğrenen Âşık Çelebi, bu kutsal topraklardan yapılan duaların kabul edileceği inancından hareketle ondan kendisine de dua etmesini ister. Muhtemelen vermiş olduğu sözü yerine getirdiğini edebî bir metinle kayıt altına almışçasına uzunca bir Âşık Çelebi övgüsüyle eserine başlayan Fevrî, yine eser sonunda ona duada bulunarak eserini bitirir. Nitekim Âşık Çelebi hacca ç1kmadan önceki talebinin yerine getirildiğine dair Fevrî’nin hac dönüşü kendisine bir mektup gönderdiğini söyleyerek memnuniyetini belirtmek için bu mektuptan uzunca bir bölümünü tezkiresine aynen kaydetmiştir. $\mathrm{Bu}$ durum eldeki bu hac seyahatnamesinin, aynı zamanda mektup tarzında yazıldığının da bir işaretidir.

Eserini oldukça sanatkârane bir tarzda kaleme alan şair, âdeta bu alandaki maharetini sergilemek istercesine ağır bir dil kullanmıştır. Şairin dili özellikle Arafat, Kâbe ve Ravza-i Mutahhara gibi kutsal mekânların tasvirinde ve Âşsı Çelebi'nin övgüsünün yapıldığı manzum ve mensur bölümlerinde daha da ağırlaşır. Şair, Arapça ve Farsça kelime ve terkiplerle yüklü bir dilin yanında anlatmış olduğu düşünceleri destekler mahiyette iktibas yoluyla sıkça ayet, hadis ve kelam-1 kibar tarzında Arapça özlü cümlelere de yer vermiştir. Eserde, yolculukta yaşanılanlardan çok; izlenimler ve bu izlenimler esnasındaki ruhî helecanlar resmedilmiştir. Yani şair, olay ve mekân tasvirlerinden çok kutsal topraklarda olmanın iç dünyasında oluşturduğu vecd hâlini terennüm etmiştir.

Sonuç olarak şimdilik elde tek yazma nüshası bulunan bu Hac Seyahat-nâme'si, hem Fevrî gibi 16. yüzyılın önde gelen şairlerinden birine ait olması hem de temsil ettiği edebî türün sıradışı örneklerinden biri olması bakımından edebiyat tarihi numunelerimiz arasında ayrı bir öneme haizdir. 


\section{Kaynakça}

Açıkgöz, Namık, Riyâzü'ş-Şu'arâ, Kültür ve Turizm Bak. Yay., Ankara 2017, e-kitap: http://ekitap.kulturturizm.gov.tr/Eklenti/54137,540229-riyazu39s-suarapdfpdf.pdf?0, [E.T. 05.08.2019].

Aksoyak, İ. Hakk1, “Nâbî'nin Tuhfetü'l-Haremeyn'inin Edirneli Nâtık'ın Tuhfetü'lHaremeyn'ine Etkisi: Hikâyeler, Gelenekler, İnanışlar...", Milli Folklor, Y11 24, S. 95, 2012, s. 9-22.

Altuntaş, Halil - Şahin, Muzaffer, Kur’an-ı Kerim Meali, Diyanet İşleri Başkanlığı Yay., Ankara 2011.

Avcı, İsmail, “Kastamonu'dan Şam'a: Mevlevî Alayı Gönüllülerinden Giritli Hayrî ve Manzum Seyahat-nâmesi”, Gazi Türkiyat, Bahar 2019, s. 1-22.

Baştürk, Sadettin, "Bir Hac Yolcusunun Gözünden İstanbul'dan Hicaz'a Osmanlı Şehirleri”, Journal of Human Sciences (10)1, 2013, s. 148-161.

Canım, Rıdvan, Tezkiretü'ş-Şu'arâ ve Tabsıratü'n-Nuzamâ, KTB. Yay., Ankara 2018, [Erişim Tarihi: 01.02.2019]. e-kitap: http://ekitap.kulturturizm.gov.tr/Eklenti/60327,latifitezkiretus-suara-ve-tabsiratun-nuzamapdf.pdf?0.

Coşkun, Menderes, "Seyahat-nâme”, TDV İslam Ansiklopedisi, C. 37, TDV Yay., İstanbul 2009, s. 13-16.

Coşkun, Menderes, Bosnalı Muhlis'in Manzum Seyahatnamesi Delîlü'l-Menâhil ve Mürşidü'lMerâhil, Fakülte Kitabevi, Isparta 2007.

Coşkun, Menderes, Manzum ve Mensur Osmanlı Hac Seyahatnameleri ve Nâbî'nin Tuhfetü'lHarameyn'i, Kültür Bakanlığı Yay., Ankara 2002.

Devellioğlu, Ferit, Ansiklopedik Osmanlıca-Türkçe Lûgat, Aydın Kitabevi, Ankara 2011.

Donuk, Suat, "Bursa Enarlı Zaviyesi Şeyhi Seyyid Mehmed Efendi ve Manzum Hac Menâzilnâmesi”, Uludă̆ Ü. Ilahiyat Fakültesi Dergisi, S. 28, 2019, s. 123-69.

Donuk, Suat, "Servet Mahlaslı Bir Şaire Mâl Edilen Manzum Bir Hac Seyahatnamesi", Selçuk Ü. Türkiyat Araştırmaları Dergisi, S. 41, 2017, s. 13-38.

Efe, Zahide, "Kâmî ve Revan Şehrengizi”, Uluslararası Sosyal Araştırmalar Dergisi, S. 66, 2019, s. 108-123.

Efe, Zahide, "Müellifleri Meçhul İki Şehrengiz: Üsküp ve Budin Şehrengizleri”, Divan Edebiyatı Araştırmaları Dergisi, S. 23, 2019, s. 271-314.

Elgün, Adnan, Kâmil, Hayatı-Eserleri ve Menâsik-i Hacc'ı, Marmara Ü. SBE, Yayımlanmamış YLT, İstanbul 2005.

Fevrî, Risâle fi'l-Menâsik, Süleymaniye Kütüphanesi, Şehid Ali Paşa 2828/3.

Flügel, Gustav, Die Arabischen, Persischen und Türkischen Handschriften Geschichte der Arabischen Litteratur (Supplementband), Leiden, 1937-42.

Göger, Veysel ve Sarıkaya, Hüseyin, "Mora'nın İstirdâdına Dair Bir Kaynak Değerlendirmesi ve Nâdir'in Vâk1'ât-1 Gazavât'1", Türk Kültürü Incelemeleri Dergisi, 20, 2009, s. 1-32.

İlgürel, Sevim, “Abdurrahman Hibrî’nin Menâsık-i Mesâlik'i”, İstanbul Ü. Edebiyat Fakültesi Tarih Enstitüsü Dergisi, (6), 1975, s. 111-128.

İsen, Mustafa, Künhü'l-Ahbâr'ın Tezkire Kısmı, Akçă̆ Yay., Ankara 1994. 
Kalpakl1, Mehmet, "Fevrî, Ahmed" http://teis.yesevi.edu.tr/madde-detay/fevri-ahmed, [Erişim Tarihi 15.04. 2020].

Kalpakl1, Mehmet, Divan Şiirinin Edisyonunda Bilgisayar Kullanımı Metoduna Giriş ve Fevrî Divanı'nın Elektronik Formu, İstanbul Ü. SBE, Yayımlanmamış DT, İstanbul 1991.

Kanar, Mehmet, Osmanlı Türkçesi Sözlüğ̈̈, Say Yay., İstanbul 2009.

Kaplan, Yunus, "Seyyid Yahyâ Vâkıf Efendi ve Halep Menzil-nâmesi”, Littera Turca Journal of Turkish Language and Literature, 6/2, 2020, s. 213-231.

Karadağ, Serbülent, Mehmed Edib Bin Mehmed Derviş'in "Behcet'ül Menazil" Adlı Eserinin Transkrip ve Tahlili, Mustafa Kemal Ü. SBE, Yayımlanmamış YLT, Hatay 2011.

Karataş, Ahmet, "Neccârzâde Şeyh Rizâ Efendi'nin Hacnâme'si”, Marmara Ü. Illâhiyat Fakültesi Dergisi 43, 2012/2, s. 185-232.

Kayabaşı, Bekir, Kaf-zâde Fâ'izî’nin Zübdetü'l-Eş'âr' $ı$, İnönü Ü. SBE, Yayımlanmamış DT, Malatya 1997.

Kılıç, Filiz, Meşâ'irü'ş-Şu'arâ, KTB. Yay., Ankara 2018, e-kitap: http://ekitap.kulturturizm.gov.tr/Eklenti/59036,asik-celebi-mesairus-suarapdf.pdf?0, [Erişim Tarihi: 01.02.2019].

Koyuncu, Fatih, “Cûdî’nin Manzum Hac Seyahat-nâmesi”, Littera Turca Journal of Turkish Language and Literature, Volume 3, Issue 1, 2017, s. 177-219.

Mutçall, Serdar, Arapça-Türkçe Sözlük, Dağarcık Yay., İstanbul 1995.

Özcan, Nurhan Ramazanoğlu, Seyyid İbrahim Hanîf'in (ö. 1802) Hayatı, Eserleri ve Hâsıl-ı Hacc-ı Şerîf Li-Menâzi'l-Harameyn Adlı Eserin Incelenmesi, Ankara Ü. SBE, Yayımlanmamış YLT, Ankara 2011.

Özuygun, A. Rıza - Yapıcı, Şefika, "Bosnalı Hacı Yusuf Livnjak'ın Hac Seyahatnamesi”, Sosyal Bilimler Araştırmaları Dergisi, S. I, 2014, s. 36-74.

Sak, İzzet ve Çetin, Cemal, "XVII. ve XVIII. Yüzyıllarda Osmanlı Hac Menzilleri”, Selçuk Ü. Illahiyat Fakültesi Dergisi, S. 19, 2005, s. 199-260.

Solmaz, Süleyman, Gülşen-i Şu’arâ, Kültür ve Turizm Bak. Yay., Ankara 2018, e-kitap: http://ekitap.kulturturizm.gov.tr/Eklenti/56733,ahdi-gulsen-i-suarapdf.pdf?0, [E.T. 01.09.2019].

Sungurhan, Aysun, Kınalızâde Hasan Çelebi, Tezkîretü'ş-Şu'arâ, Kültür ve Turizm Bak. Yay., Ankara 2017, e-kitap: http://ekitap.kulturturizm.gov.tr/belge/1-83504/kinalizâde-hasancelebi---tezkiretus-suara.html, [E.T. 01.03.2019].

Uzun, Mustafa İsmet, "Kâbe”, TDV İslam Ansiklopedisi, C. 24, TDV Yay., İstanbul 2001, s. 2326.

Yazıc1, Hüseyin, “Seyahat-nâme”, TDV İslam Ansiklopedisi, C. 37, TDV Yay., İstanbul 2009, s. 9-11. 


\section{Summary}

While Fevri was a devshirmeh of Croatian origin, he was one of the important Ottoman poets who received a great education as a Muslim and gained eligible reputation with his scholarly virtues and ability in being a poet in 16th century. The scholarly literary works that he wrote them became a great role for him to gain the reputation. Pilgrimage Travelbooks that he told the travel that he started out on the occassion of his duty of pilgrimage in 1546 and told a part of what he had and saw during the performance of the worship and he wrote in a mixed poetic-prose form is available among these works.

His work which has been overshadowed of other works and has not been focused too much has a especial importance in terms that the poet reflected a different literary dialect and it has a different type among his works. Moreover, this work has an importance because it is in the type of pilgrimage itinerary that their samples are limited in the classic Turkish literature.

Fevrî took his pilgrimage journey in 1544 as a subject of this work. As it is stated in Meşấirü'ş-Şuarâ, Aşık Chelebi learns that Fevrî will go on pilgrimage and asks him to pray for him as well, based on the belief that the prayers made from these holy lands will be accepted. Fevrî started his work with long praise of Âşı Chelebi, as if recording with a literary text that he probably fulfilled his promise, and finished his work by praying to him at the end of the work. As a matter of fact, Aşı Çelebi recorded along part of this letter exactly in his biography in order to express his satisfaction by saying that Fevri sent him a letter on his return from the pilgrimage stating that his request before he went on the pilgrimage was fulfilled. This is a sign that this pilgrimage booklet is also written in letter style.

The poet, who wrote his work in a very artistic style, used a heavy language as if he wanted to exhibit his skill in this field. The language of the poet becomes heavier especially in the description of sacred places such as Arafat, Kaaba and Ravza-i Mutahhara and in the poetic and prose parts where Âşı Çelebi is praised. The poet frequently included Arabic concise sentences in the style of verses, hadiths, and polite words, in a way that supports the thoughts he expresses in addition to a language loaded with Arabic and Persian words and compositions. In the work, more than what happened during the journey; impressions and spiritual flippers during these impressions are depicted. In other words, the poet chanted the state of ecstasy he created in his inner world of being in the holy land rather than depicting events and places.

In this research, a set of evaluations was made on the form and content features of Pilgrimage Travelbooks belonging to Fevri from the point of its available single copy and the work's text in translated and written form was included. 